\title{
Urban Metabolism of Bangalore City: A Water Mass Balance Analysis
}

Reba Paul ${ }^{1}$, Steven Kenway ${ }^{2}$, Brian McIntosh ${ }^{3}$ and Pierre Mukheibir ${ }^{4}$

\section{Address correspondence to:}

\author{
Reba Paul \\ Doctoral Researcher and Research Assistant \\ Institute for Sustainable Futures (ISF) \\ University of Technology Sydney \\ Level 11, Building 10 \\ 235 Jones Street, Ultimo NSW 2007 \\ Email: reba.paul@uts.edu.au
}

This is a proof for the purposes of peer review only. 


\section{Abstract}

Cities are increasingly depending on energy intensive water sources such as distant rivers and the ocean to meet their water demand. However, such expensive sources could be avoided using alternative local sources of water such as wastewater, rainwater and stormwater. Many cities do not have robust accounts of those localized water resources, as estimating those resources requires comprehensive accounting in complex urban water systems. In this article, we investigated whether an urban metabolism evaluation framework built on the Urban Water Mass Balance can help analyze these resources, especially in a rapidly growing developing city. We first refined the water mass balance equation developed by Kenway et al. (2011) for a developing country context with the inclusion of some significant components such as system loss. Then we applied it to Bangalore city for the year 2013-2014 which is a rare mass balance analysis in a developing country. The refined equation helped analyze Bangalore urban water system. The total available wastewater, stormwater and rainwater were 656 gigaliters. The gap between water demand and supply could be met if $54 \%$ of this recycled potential were harnessed. Wastewater had enough potential (362 gigaliters) to replace the whole centralized water supply from the Cauvery. A scenario analysis showed that the gap between water demand and supply in 2021 can be met if $60 \%$ of total recycled potential is utilized. This approach can be used to other cities to identify the potential of alternative water sources and help integrated water planning and monitoring water metabolic performances.

Keywords: urban water accounting, system boundary, alternative water resources, water reuse. urban water planning, water performance indicator 


\section{Introduction}

The growing population, urbanization and global climate change will increase demand for water, energy and other resources. By 2050, about two third of the world's population will be living in cities or urban areas (UN 2014). In 2014, 54\% of the world's population was already living in urban areas (UN 2014). Fast growing cities will be facing serious problems to meet basic services needed for their people in terms of limited world resources such as water, energy and nutrients. Further, the current practice of linear (without resource reuse) management of resources is pushing cities to depend on their hinterlands to cope with growing pressures of resource supplies, which in many cases requires substantial energy (Bai 2007; Kenway et al. 2011; Kennedy et al. 2011; Agudelo-Vera et al. 2012).

Water is a major resource in an urban system which requires dedicated management attention. In 1965, Abel Wolman pioneered the use of Urban Metabolism as an evaluation framework to analyse a hypothetical American city (New York) with one million population. Wolman developed this concept to address the water and air quality of American cities (Wolman 1965). His study included only the inputs of centralized flows of water managed by urban infrastructure and estimated that the input of water was 625000 tons/day for one million people in the United States of America compared to just 9500 tons and 2000 tons of fuel and wood respectively (Wolman 1965). Most of this inflow is discharged as wastewater with the remainder being lost by various human activities. His study showed that wastewater (outflow) represents between $75 \%$ and $100 \%$ of supplied water (inflow). This was further stressed by Larsen et al. (2016) in her review article on 'Emerging Solutions to the water challenges of an Urbanized World'. The huge percentage of this wastewater can be tapped to meet urban water 
demand to avoid importing of remote water resources which involves substantial energy. Again system loss from a centralized urban water system is very significant in many developing cities from 30-50\% example for Bangalore city (CSE 2011; Raj et al. 2013; Mehta et al. 2014; Kingdom et al. 2012) This water loss has also high potential to reduce water demand in supply main.

Few cities globally have a comprehensive accounting of their urban water resources. Systematic quantification requires good data and a thorough understanding of resources available (Kennedy et al. 2010; Kenway et al. 2011; Renouf et al. 2016). An urban metabolism framework provides a broader picture of resources flow as well as quantitative analysis of all inputs and outputs, stock of water, energy, waste, nutrients and other materials (Wolman 1965; Kennedy et al. 2010; Kenway et al. 2011). This can be used as a conceptual and analytical framework (Kenway at al. 2011, Renouf et al. 2016; Farooqui et al. 2016).

There are many approaches and methods for analyzing resources flow in urban water systems such as 'Life Cycle Assessment (LCA)', 'Environmental Footprints' and 'Integrated Water Cycle Modelling'. LCA quantifies the resource use embodied in goods and services in an urban system (such as water and energy foot prints), 'Environmental Footprints' originates in LCA, and the Inputs-Outputs analysis is a top-down method to quantify resources flows through an entire urban entity or economy (both direct and indirect flows). Integrated Water Cycle Modelling considers a water system within an urban entity such as a precinct but not the entire urban entity or whole economy (Bach et al. 2014). 
Urban metabolism can be used at different scales from global to city and household levels (Agudelo-Vera et al. 2012) and can generate inventories of resources flow (water, energy, nutrients/pollutants, carbon and other materials) over time with trends of resource utilization (Kennedy et al. 2007). Such accounting also helps compare from city to city (Kennedy et al. 2015).

Since Wolman (1965), several studies have been undertaken on Urban Metabolism, however few focused on water (Kenway et al. 2011; Hermanowicz and Asano 1999; Baker et al. 2001; Thériault and Laroche 2009; Kenway et al. 2011). Kenway et al. (2011) developed a comprehensive Water Mass Balance Framework for a better understanding of water and related energy and material flows in cities, however system losses were not incorporated and can be a significant component of an urban water mass balance in a developing city. There are also other flows in a developing city such as water supplied by various water retailers (Raj 2013) which are important. Moreover, urban water mass balance analysis has been done so far for a limited number of cities as real case studies (Kenway et al. 2011; Farooqui et al. 2016).

Consequently, in this study, we first refine the original water mass balance developed by Kenway et al. (2011) for a developing country context. Then we apply this to Bangalore, a fast growing developing city, as a real case study.

\section{Literature Review}

Studies on Urban Metabolism focusing on water after Wolman were done in 
the cities of Hong Kong, Toronto, Tokyo, Vienna, Brussels, London, Cape Town, Sydney as well as other Australian cities (Duvignead and Denaeyer-De Smet 1997; Hendriks et al. 2003; Gasson 2002; Chrysoulakis et al. 2015; Chartered Institute of Waste Management 2002; Sahely 2003; Gandy 2004; Kennedy et al. 2007, Decker et al. 2000; Browne et al. 2011; Kenway et al. 2011; Holmes and Pincetl 2012; Renouf and Kenway 2016). Kennedy et al. (2010) did an extensive literature review on Urban Metabolism which included more than 50 papers on cities from eight global regions. His study showed that most Urban Metabolism studies had focused on the quantification of flows of energy, wastes, nutrients, materials, food, greenhouse gas emissions (GHG), food and eco-foot prints (Bhole 1994; Zucehetto 1995; Hanya and Ambe 1976; Nilson 1995; Huang 1998; Warren-Rhodes and Koenig 2001; Barrett et al. 2002; Baker et al. 2001; Gasson 2002; Zhang et al. 2009; Forkes 2007; Barles 2009). Only three papers in his study focused on water (Hermanowicz and Asano 1999; Baker et al. 2009; Gandy 2009). Some studies in his literature review were related to livability (Newman et al. 1999) and eco-efficiency (Zhang and Yang 2007) and others were on comprehensive metabolism study (Newcombe et al. 1978 and Stimson et al. 1999). The per capita water use and wastewater flow of some cities as reported in Kennedy et al. (2007) (figure 1) illustrates that urban metabolism of cities (example for Sydney, Hong Kong from available data) are increasing over time. In the case of Toronto, the per capita water use declined over 1990s from 1970s which was due to reduction in industrial water consumption (Kennedy et al. 2007). 


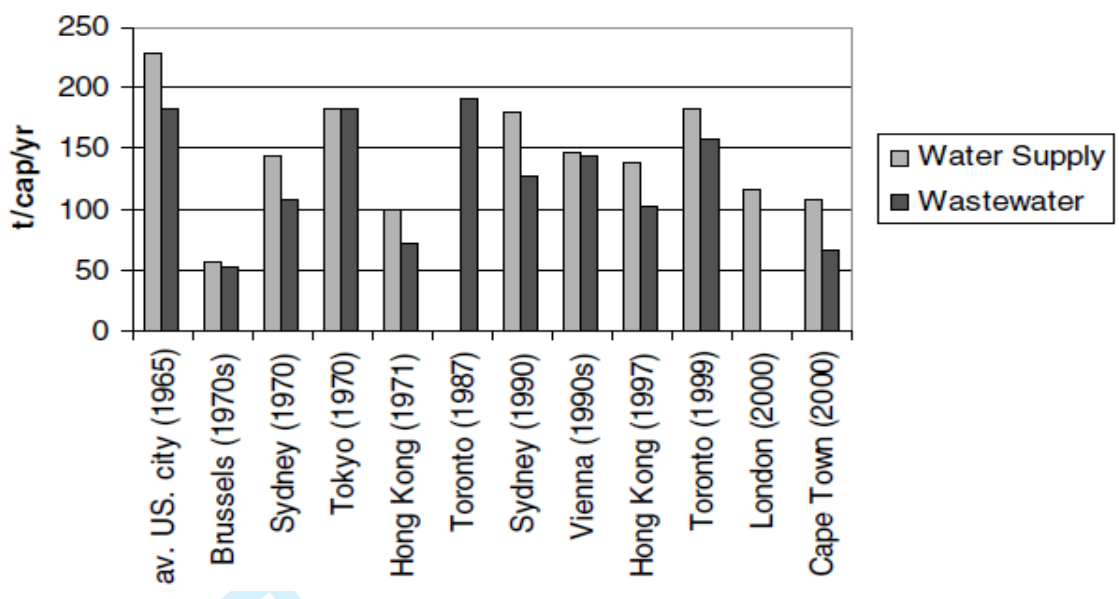

Figure 1: Inputs and Outputs of water flows in selected cities (Source: Kennedy et al. 2007) Note: $\mathrm{t} / \mathrm{cap} / \mathrm{yr} .=$ tons/capita/year. One ton $(\mathrm{t})=10^{3}$ kilograms (weight of 1 kiloliter water). So $\mathrm{t} / \mathrm{cap} / \mathrm{yr}$. can be represented in volume as $\mathrm{kL} / \mathrm{cap} / \mathrm{yr}$.

A comprehensive Water Mass Balance considering all components of an urban water cycle (rainwater, imported supply, decentralized water, wastewater, stormwater, evapotranspiration, groundwater recharge and water reuse) rather counting just inputs and outputs as a whole (figure 1) is of utmost importance for better understanding of urban water metabolism of cities facing increased water scarcities so as to find alternative local water sources and quantify their recycling potentials. But past studies followed the method of Materials Flow Analysis (MFA). A MFA provides 1) the overall mass fluxes of resources (energy, materials, food and pollutants such as nutrients, carbon), 2) helps understand the use of resources and their trends over time, and 3) assists environmental reporting (Kennedy et al. 2007; Kenway et al. 2011; Renouf et al. 2016). But when it comes to water, MFA cannot integrate individual flows such as decentralized water supplies, or hydrological flows such as rainwater, groundwater infiltration, surface runoff, and evapotranspiration so cannot provide information for the improved and holistic management of water resources. This was first 
understood by Kenway et al. (2011), who developed a comprehensive Urban Water Mass Balance Framework for a better understanding of water and related energy and material flows in a city.

Kenway et al (2011) explained the critical importance of a clear system boundary to define the volume flowing across the boundary and volume stored within the boundary, as shown in figure $2 \mathrm{a}$ (Kenway et al. 2011). If B is a defined system boundary and A is the boundary area with a depth d, water mass balance based on principles of mass conservation is inputs (Qi) minus outputs (Qo) and the change in storage (volume or mass) $\Delta \mathrm{S}$ in the system boundary over a time period $t_{1}-t_{2}$ can be expressed in equation (1).

$$
\Delta \mathrm{S}=\left(\mathrm{S}_{\mathrm{t} 1}-\mathrm{S}_{\mathrm{t} 2}\right)=\mathrm{Qi}\left(\mathrm{t}_{1}-\mathrm{t}_{2}\right)-\mathrm{Qo}\left(\mathrm{t}_{1}-\mathrm{t}_{2}\right)
$$

For a particular system, if time interval and system boundary have been defined and all units are expressed as volumes or masses flowing through per unit time, equation (1) can be simplied as follows:

$$
\Delta \mathrm{S}=\mathrm{Qi}-\mathrm{Qo}
$$



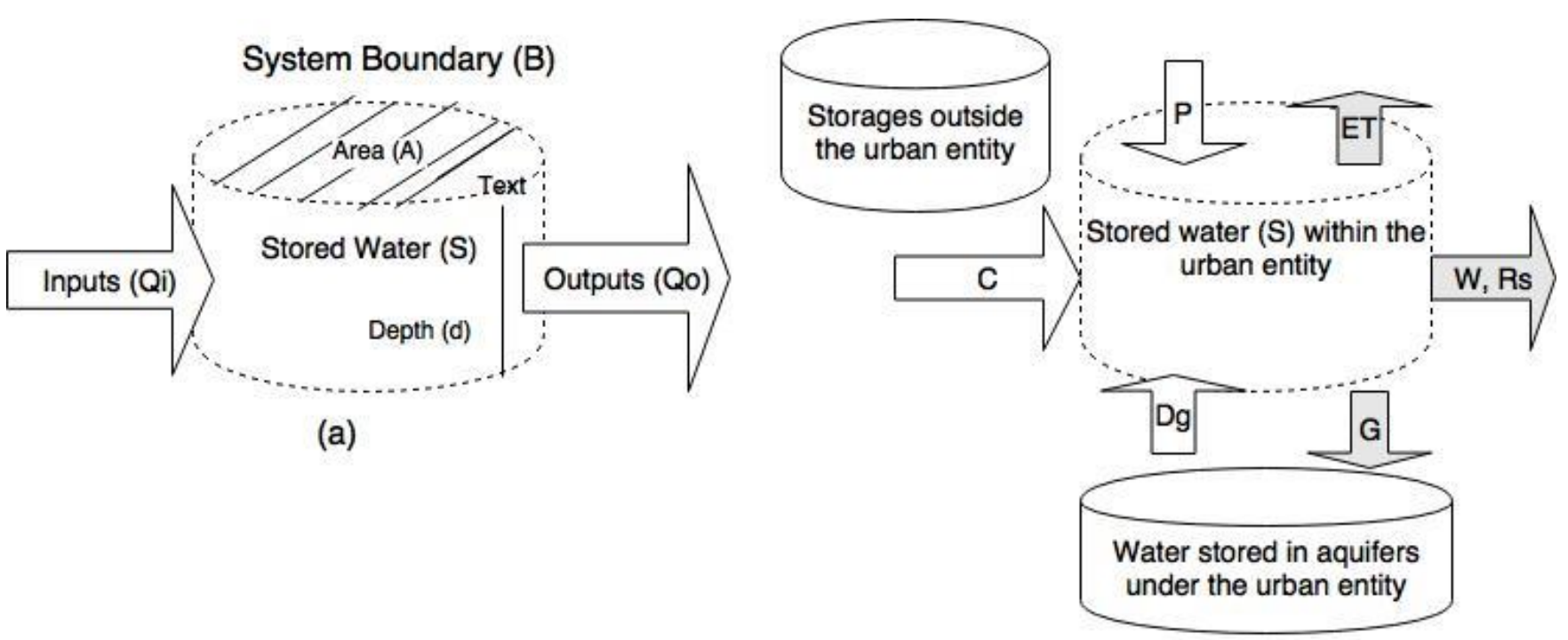

(b)

Figure 2: a) Defining System Boundary and b) Water Mass Balance Framework considering groundwater under the urban entity and storages outside the urban entity (Sources: adapted from Kenway et al. 2011).

In Figure 2b,

P - Precipitation or rainfall

ET- Evapotranspiration

C - Centralized water supply

S - Water stored by different subsystems

W - Wastewater

Rs- Stormwater runoff G - Groundwater

Dr - Decentralized water from rainwater

Dg- Decentralized water from groundwater

Rs - Surface runoff

Following equation 2, S = Qi-Qo

This is a proof for the purposes of peer review only. 
From figure $2 b, \quad S=(P+C+D r+D g)-(W+R s+G+E T)$

$S$ can be further defined as $S=\sum Q i$ (sum of all inflows) - $\sum Q \circ$ (sum of all outflows)

Kenway et al. (2011) used this comprehensive urban water mass balance framework for real case studies in Australian cities (Melbourne, Sydney, Brisbane, Gold Coast and Perth) to assess the potential of alternative water supply options to augment centralized inputs and reduce outputs. The framework included alternative sources of water such as rainwater, surface runoff, wastewater, decentralized water supply, evapotranspiration and groundwater infiltration. Recently this framework was further refined by Farooqui et al. (2016) by incorporating other flows such as decentralized recycled water within and outside an urban system. But Renouf et al. (2016) reported that the framework has further scope to develop by incorporating water use for ecosystem services. But they did not still underscore how this framework can be fit into a developing country context.

Every city has its unique characteristics in respect to its water management and geographical location. Urban Water Metabolism Evaluation Framework (UWMF) may differ based on a city's typology (system boundary, types of water supplies/inputs, uses, reuses, losses, scales, time and other factors). Further past studies followed different scales, approaches and perspectives of UWMF (Kenway et al. 2011 and Farooqui et al. 2016). Moreover, the latest UWMF still does not include components such as system loss which is a significant flow component of UWMF (30-50\%) in developing countries and also in some other parts of the world (CSE 2011; Kingdom et al. 2012; Raj 2013; Mehta et al. 2014). It also has large impact on hydrological cycle. One evidence is the study done by Mehta et al. (2014). He used Lump Model under a social-ecological framework, considering the loss of water from city 
pipelines and city return flows with a number of assumptions because of the unavailability of data to measure the groundwater recharge and variation in groundwater table in Bangalore. His study found that the ground water table in Bangalore has increased in the core city area but not in the periphery of the city where people experience more shortage of water and extract ground water (Mehta et al. 2014). Kenway et al. (2011) also strongly recommended for incorporation of such components within a defined system boundary to get better mass balance results. Among other water flows in developing countries, water supplied by retailers or water tankers are increasing when the utilities are failing to provide adequate water supply to the city people. Such components need to be included in UWMF for a comprehensive water mass balance analysis. In this study, we have refined the Urban Metabolism framework built on Water Mass Balance developed by Kenway et al. (2011) by incorporating system loss and other supplies to fit into a developing country context.

Kenway et al. (2011) identified that a system boundary helps incorporate all water inputs and outputs within an urban water system. Prior to Kenway et al. (2007), Water Balance of an urban catchment was described by Mitchell et al. (2003) and Sahely et al. (2003). They made efforts to include key inputs and outputs, but they excluded many components in absence of a system boundary in their analysis. Again, Mitchell et al. (2003) used a water balance equation to know the hydrological performance of a catchment but not the performance of an urban entity. Sahely et al. (2003) however, used it for cities; no system boundary was followed except for the 'greater Toronto' area and they used wastewater and storm water as a joint output, with other flows not clearly incorporated. In 1991, Baccini and Brunner developed MFA which was able to quantify the stocks and flows of resources in terms 
of mass but it also did not consider a system boundary. In this study, selection of a system boundary was given due importance to incorporate all inputs and outputs in Bangalore city.

Kenway et al. (2011) also developed some performance indicators such 'supply centralization', 'Centralized supply replaceability' and 'total water use replaceability' of wastewater, rainwater and stormwater and developed methods to calculate these indicators for a city (table 1). They applied these indicators in a number of Australian cities and found variation from $0.1-22 \%$ in rainfall harvesting, $257-397 \%$ in centralized replaceability by rainfall, $26-86 \%$ replaceability potential of wastewater recycling, $47-104 \%$ in stormwater reuses potential and 1-4\% in reuse of anthropogenic inputs water in 2004-2005. These indicators illustrate that these cities are not designed appropriately to use the full potential of these substantial flows and those are rather dependent on centralized fresh water supplies. But Perth is an exception where recycled water is used to a great extent (Kenway et al. 2011). As mentioned earlier a UWMF depends on various factors for a particular urban setting and considerations of various water flows in and outside of a city. The new indicators could be evolved, for example for 'water loss recovery' and could become important urban water performance indicators in a developing country context.

The literature review found that a Urban Metabolism Framework built on Water Mass Balance is useful to analyse complex urban water systems, but this framework has not yet been tested with real cases in developing countries, for example the Urban Water Metabolism Evaluation framework (UWMF) of Kenway et al. (2011) refined by Farooqui et al. (2016) was tested for a hypothetical urban development area in Australia. In this study, we have 
applied the refined Urban Metabolism framework/equation to Bangalore, a fast growing developing city as a real case example.

\section{Background of Bangalore City}

Bangalore (officially called Bengaluru, the capital of Karnataka State in South India) is a mega city situated in inland, in the middle of a semi- arid region of India. It is one of the fastest growing city in India and the population was 8.5 million in 2011(Census of India. 2011). It is a hub for education, IT \& BT industries, sophisticated high tech health care and many MNC industries and has nice climate which attract people to the city. The city is naturally water scarce and has no perennial source of water in the city except some seasonal lakes and waterbodies which are now polluted (CSE 2011; Lele et al. 2013; CGWB 2011). Groundwater is overexploited and polluted by nitrates, pathogens and other contaminants (Mehta et al. 2013). The water bodies have been filled up from rapid urbanization. The city now brings water from a distant freshwater source (the Cauvery River, $100 \mathrm{~km}$ away and 500 meter below the city) without due consideration of energy and cost, a disregard for the conflicts over the shared river between its four states for irrigation, hydropower, water supply and other needs, and dismissal of the process' ecological footprints (Gronwall, 2008, Novotny, 2010). BWSSB spends $60-70 \%$ of their annual operating budget for energy to provide water services to the people (CSE 2011; IBM 2010). The Cauvery Water Dispute Tribunal has earmarked 1,470 MLD or 600 Cusec for Bangalore city for its water supply (CSE 2011; Lele et al. 2013). There is no further scope for Bangalore to withdraw water from the Cauvery River as per the Tribunal agreement (Raj, 2013). However, Bangalore is still looking for more abstraction of water 
from the Cauvery (Raj 2013).

Bangalore also faces power crisis, and the city is dependent on its State Karnataka to supply energy. On May 6, 2014, the Energy Minister announced that the current daily power cuts would vary from 2-6 hours across the state. In Bangalore core area it was two hours daily, with northern Bangalore influenced the most with more than six hours without power daily. (The Times of India 2014; The Hindu 2014).

Neither Bangalore nor any other city in India enjoys a 24 hour continuous water supply. The piped water supply in Bangalore is intermittent and available only for a few hours a day (World Bank 2013; Raj 2013). Even the wealthy in Bangalore receive 2-4 hours water supply on alternate days ((Raj 2013). The rich install expensive water tanks, pumps and filters while the poor struggle to access water (World Bank 2013; Raj 2013). Further people in Bangalore has low per capita water consumption (75 lpcd) which is much below the requisite standard 150-200 lpcd (Raj 2013). This is due to a huge system loss or 'Unaccounted- for Water' (UFW) or NonRevenue Water (NRW) which varies from 55-60\% (CSE 2011; Raj, 2013). Leakage alone is estimated at 37-40\% of supply (Mehta et al. 2013). People who live in slums receive no water or a much lesser quantity (CSE 2011 and Lele et al. 2013).

\section{Methodology}

\section{Selecting System Boundary}

Identifying a system boundary is very important for a comprehensive water mass 
balance analysis that considers all inflows and outflows within and throughout a city (Kenway et al. 2008)]. In this study, we define the system boundary as the core of Bangalore city and the adjacent built up area that is the Bangalore Water Supply and Sewerage Board (BWSSB) service area, called greater Bangalore, including $1 \mathrm{~km}$ under ground level (figureS 1). The subsystem boundaries have been identified as Water Treatment Plants (WTPs), Wastewater Treatment Plants (WWTPs), various sub-sectors or land uses such as residential, commercial, industrial, public and semi-public institutions, parks and open space, transport and communication, agriculture and lakes and ponds. Water storage outside the city and ground water aquifers beneath the city has not been considered part of the system. The inflows into and outflows from the city through natural waterbodies and streams have also been excluded in order to separate the city from the natural environment, as done by Kenway et al. (2011). The subsystem boundaries and their percentages compared to the system boundary are shown in table S 1 . These values were used for the calculation of sub-boundary precipitation, runoff and groundwater recharge. The land use by WTP and WWTP were considered as negligible compared to the area of the system boundary, which is 800 sq.km(BWSSB 2013). 
This is a proof for the purposes of peer review only.

Figure 3: Water Mass Balance Evaluation Framework (Refinement of original framework developed by Kenway et al. (2011) to apply for a developing country context)

In figure 4,

$$
\begin{aligned}
& \mathrm{P}=\text { Precipitation or Rainfall } \\
& \text { ET }=\text { Evapotranspiration } \\
& \mathrm{C}=\text { Centralized water supply } \\
& \mathrm{S}=\text { Water stored or utilized by different subsystems } \\
& \mathrm{W}=\text { Wastewater flow } \\
& \mathrm{Rs}=\text { Stormwater runoff } \\
& \mathrm{G}=\text { Groundwater flow/recharge } \\
& \text { Dr }=\text { Decentralized rainwater supply } \\
& \text { Dg = Decentralized groundwater supply }
\end{aligned}
$$


Dsw $=$ Decentralized surface water supply by private retailers/tankers

$\mathrm{C}_{\mathrm{ufw}}=$ System loss/leakages (Unaccounted for Water/Non-Revenue Water)

$\mathrm{Rs}=$ Surface water runoff $\mathrm{Rw}=$ Recycled water

$\mathrm{S}=(\mathrm{P}+\mathrm{C}+\mathrm{Dr}+\mathrm{Dg}+\mathrm{Dsw}+\mathrm{Rw})-\left(\mathrm{W}+\mathrm{Rs}+\mathrm{G}+\mathrm{ET}+\mathbf{C}_{\mathbf{u f w}}\right)$

Table 1: Performance indicators and their definition under the study

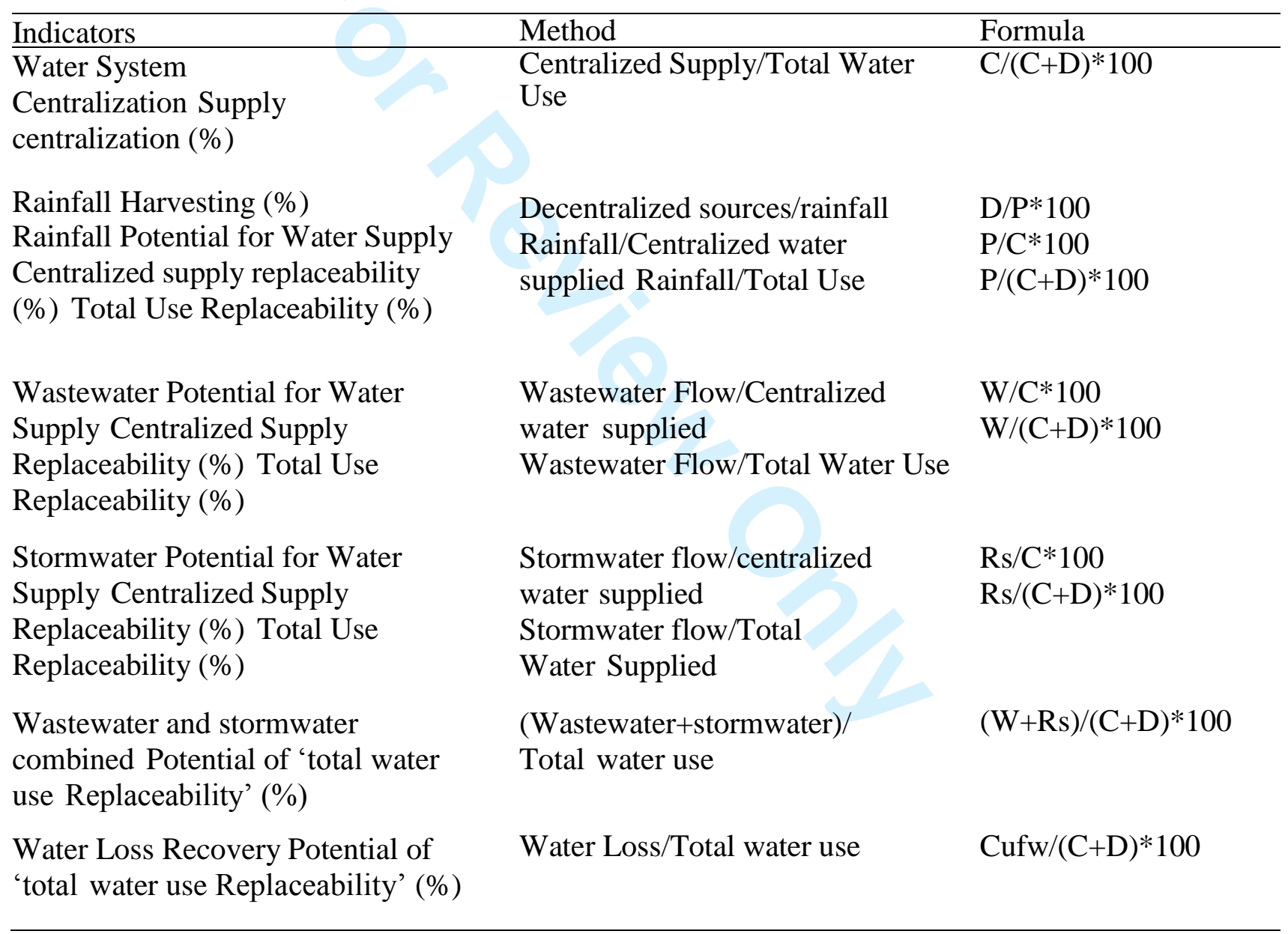

Source: Adapted from Kenway et al. (2011)

Note- $\mathrm{C}=$ Total Centralized Water Supply, D=Total Decentralized Water Supply, P= Rainfall,

W=Wastewater Flow, Rs= Stormwater Runoff , Cufw= Uncounted For Water

This is a proof for the purposes of peer review only. 


\section{Data collection and Interpretation}

Both secondary and primary data were collected based on the Water Mass Balance Framework described in figure 3, developed from the original framework by Kenway et al. (2011) (figure 2), and have been discussed in details in the supplementary Information.

Based on the availability of data, the time period for the study was considered as 20132014 (Jan-Dec).

The area of the system boundary, population, decentralized water supply, groundwater supply and other parameters were collected from various research reports, journals and official Information. The primary data for centralized water supply, wastewater generation and wastewater reuse, and rainfall for the year 2013-2014 was collected from Bangalore Water Supply and Sewerage Board (BWSSB) and Meteorological Centre, Bangalore and other government Information. These have been discussed in details in supplementary Information.

The water cycle in Bangalore is managed by various organizations such as BWSSB (responsible for water supply and sewerage), CGWB (groundwater monitoring and management), BBMP (Bhurat Bangalore Mahanagar Pallika) (stormwater drainage and solid waste management), Bangalore Development Authority (BDA) (city planning), private water suppliers and self-suppliers with overlapping responsibilities. There is no central water database for the city water supply which made measuring various inputs and outputs a challenging task. 
Rainwater use, negligible compared to total water supply, was calculated based on rainwater plants installed in Bangalore city and assumed an average plant discussed in details in supplementary Information.

Measuring groundwater recharge was difficult due to the unavailability of continuous water table monitoring data in Bangalore city. It was therefore calculated following the detailed Guidelines for Implementing Groundwater Estimation Methodology (CGWB 2009) and the Groundwater Resource Estimation Methodology (GEM) Report -1997 (MoWR 2009) recommended by Groundwater Resource Estimation Committee (MoWR 2009) elaborated in supplementary information.

The runoff coefficient for various land uses have been used for this study based on the typical values of runoff coefficients in an urban area as elaborated in Chapter-11 of the Urban Drainage Book (Butler and Davies 2011). Evapotranspiration for sub-boundaries has been calculated with the following formula from respective values: ET = P-R-G.

\section{Results and Discussion}

The collected primary and secondary data were used for the water mass balance analysis of Bangalore city using the water mass balance equation described in methodology section and also mentioned below. The results of this analysis have been shown in table 2 . All inputs and outputs are considered in the analysis (details of water mass balance flow chart can be seen in figure S 5). The equation was applied to both system and sub-system boundaries, and found a positive change of 130.58 gigaliters (GL) in the storage of the city 
system:

$$
\begin{aligned}
& \mathrm{S}=\text { Inflows }- \text { Outflows } \\
& \mathrm{S}=(\mathrm{P}+\mathrm{C}+\mathrm{Dr}+\mathrm{Dg}+\mathrm{Ds}+\mathrm{Rw})-\left(\mathrm{W}+\mathrm{Rs}+\mathrm{G}+\mathrm{ET}+\mathrm{C}_{\mathbf{u f w}}\right) \\
& \mathrm{S}=(77.6+356.3+0.004+288.4+23.73+2.9)-(362+40+4.4+33.28+178.6) \\
& =(749)-(618) \\
& =131 \mathrm{GL}
\end{aligned}
$$

One Gigaliter $(\mathrm{GL})=10^{9}$ liters $(\mathrm{L}) \approx 2.64 \times 10^{8}$ gallons $($ gal $)$.

In reality inputs should be equal to outputs (Kenway et al. 2011). The high value of change in storage may be due to some errors in calculation when quantifying the ground water recharge value, use of assumed runoff co-efficient and other data inaccuracy. Further, only data for the year 2013-2014 were used due to data unavailability. The data accuracy, appropriate runoff coefficient in respect to Bangalore geography and soil situation, and a longer timeframe for data could provide better results of water mass balance equation.

The total water availability of rainwater, stormwater and wastewater was 656 Giga liters (GL) during the year 2013-2014 considering full reuse potential.

The water performance indicators were derived based on the formula described in table 1 , the results of which have been tabulated in table 3 and table 4 .

The 'water supply centralization' of Bangalore city was $52 \%$ which illustrates that the 
Bangalore water supply system is not fully centralized. About $48 \%$ of water demand is met from groundwater and other sources. The 'total water use replaceablity' of wastewater was $55 \%$ and centralized replaceability was $107 \%$ which means the amount of wastewater (362 GL) could solely replace present centralized water supply in 2013 ( 356 GL), imported from the Cauvery river. The 'total use replaceability' of alternative rainwater and stormwater was $12 \%$ and $6 \%$, respectively, which illustrates that $78 \mathrm{GL}$ and $40 \mathrm{GL}$ could be used as inputs in the whole urban system from these two sources. The replaceability potential of wastewater (362 GL) is about 5 times and 9 times higher than rainwater (78 GL) and stormwater (40 GL), respectively, which indicates Bangalore is a dry city.

Table 2: Inputs (Qi) and Outputs (Qo) of Bangalore city for the year 2013-2014

\begin{tabular}{|c|c|c|c|c|c|c|c|c|}
\hline Inputs & $\begin{array}{l}\text { Population } \\
\text { (Million) }\end{array}$ & $\begin{array}{l}\text { Area } \\
(\mathrm{Sq} . \\
\mathrm{km})\end{array}$ & $\begin{array}{l}\text { Centralized } \\
\text { Surface } \\
\text { Water } \\
\text { Supply } \\
\text { (GL/a) }\end{array}$ & $\begin{array}{l}\text { Decentralized } \\
\text { Groundwater } \\
\text { Supply } \\
\text { (GL/a) }\end{array}$ & $\begin{array}{l}\text { Decentralized } \\
\text { Surface Water } \\
\text { Supply (GL/a) }\end{array}$ & $\begin{array}{l}\text { Decentralized } \\
\text { rainwater } \\
\text { supply(rainw } \\
\text { ater tank) } \\
(\mathrm{GL} / \mathrm{a})\end{array}$ & $\begin{array}{l}\text { Rainfall } \\
\text { on } \\
\text { Surface } \\
\text { (GL/a) }\end{array}$ & $\begin{array}{l}\text { Reuse of } \\
\text { Wastewater } \\
\text { (G/a) }\end{array}$ \\
\hline & 9.5 & 800 & 356 & 288 & 24 & 0.004 & 78 & 3 \\
\hline Outputs & $\begin{array}{l}\text { Population } \\
\text { (Million) }\end{array}$ & Area & $\begin{array}{l}\text { Partially } \\
\text { Treated } \\
\text { Waste } \\
\text { water } \\
\text { Flow } \\
(\text { GL/a) }\end{array}$ & $\begin{array}{l}\text { Non-Treated } \\
\text { Wastewater } \\
\text { Flow } \\
\text { (GL/a) }\end{array}$ & $\begin{array}{l}\text { Treated } \\
\text { Wastewater } \\
\text { Flow } \\
\text { (GL/a) }\end{array}$ & $\begin{array}{l}\text { Surface } \\
\text { Runoff } \\
\text { (GL/a) }\end{array}$ & $\begin{array}{l}\text { System } \\
\text { Loss } \\
\text { (GL/a) }\end{array}$ & $\begin{array}{ll}\text { Ground } & \text { Evapo- } \\
\text { Water } & \text { Transp } \\
\text { Recharge } & \text { iration } \\
\text { (GL/a) } & \text { (GL/a) }\end{array}$ \\
\hline & 9.5 & 800 & 167 & 171 & 24 & 40 & 179 & 4.4 \\
\hline
\end{tabular}

Note: GL/a =Gigaliter/annum

This is a proof for the purposes of peer review only. 
The total inputs $(749 \mathrm{GL})$ and outputs $(618 \mathrm{GL})$ of Bangalore city and their different components have been shown in figure 4.

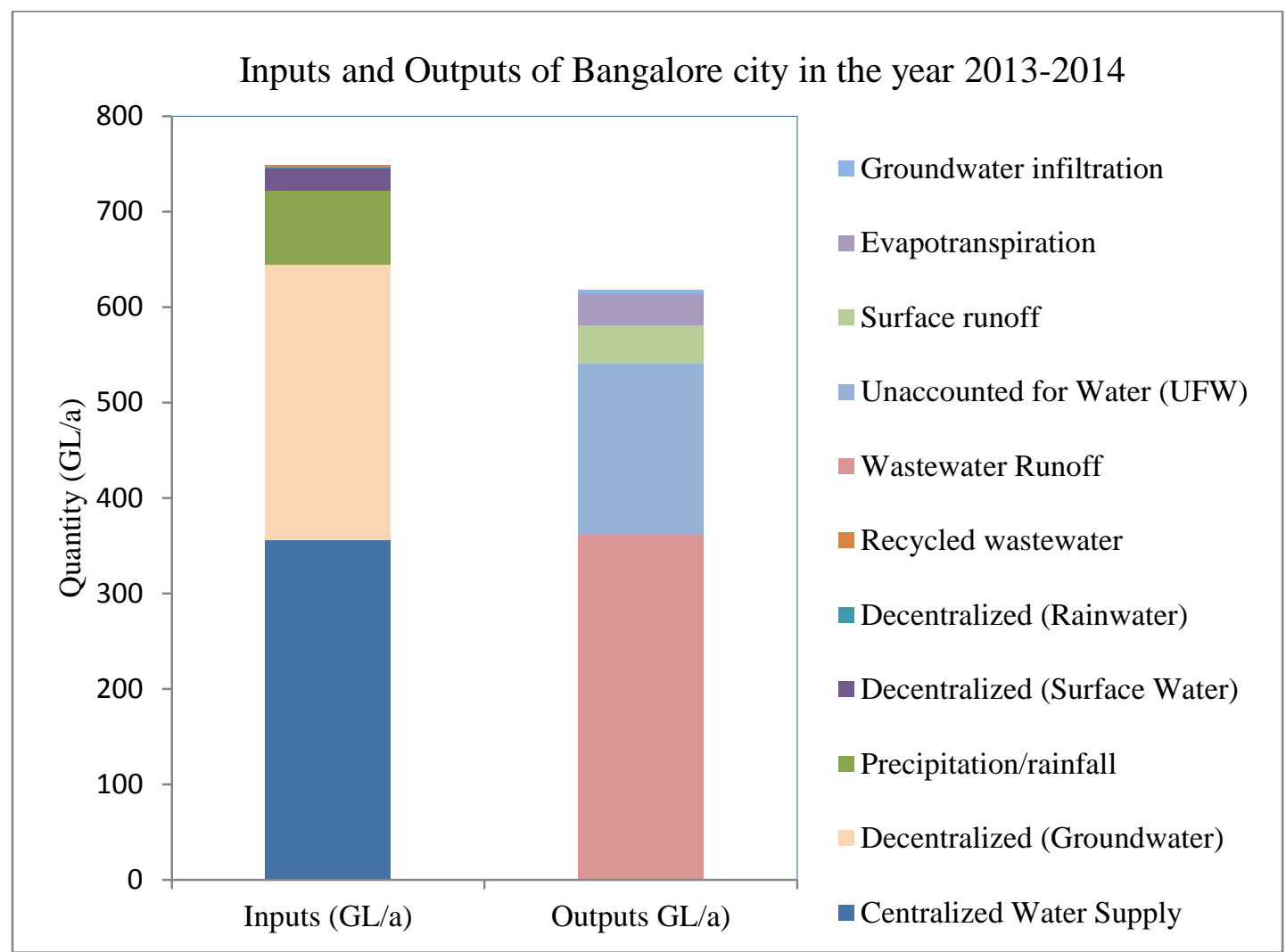

Figure 4: Inputs and Outputs of water in Bangalore city for the year 2013-1014.

Table 3: Centralized Supply Replaceability/ Supply Substitution of alternative sources of water including loss in the system for the year 2013-2014

\begin{tabular}{|c|c|c|c|c|c|c|c|}
\hline \multicolumn{8}{|c|}{$\%$ of potential replaceability/substitution of water supply } \\
\hline Supply & $\begin{array}{l}\% \\
\text { Total } \\
\mathrm{C} /(\mathrm{C}+\mathrm{D}) \\
* 100\end{array}$ & $\begin{array}{l}\text { of Rain } \\
\text { Water } \\
\text { (P/ } \\
\left.\mathrm{C}^{*} 100\right)\end{array}$ & $\begin{array}{l}\text { Storm } \\
\text { Water } \\
\text { (RS/ } \\
\text { C*100) }\end{array}$ & $\begin{array}{l}\text { Waste } \\
\text { Water } \\
(\mathrm{W} / \\
\left.\mathrm{C}^{*} 100\right)\end{array}$ & $\begin{array}{l}\text { Unaccounted } \\
\text { For Water } \\
\text { (UFW)/Non- } \\
\text { Revenue } \\
\text { Water (NRW) }\end{array}$ & $\begin{array}{l}\text { Waste } \\
\text { water and } \\
\text { Rainwater } \\
\left(\mathrm{W}+\mathrm{P} / \mathrm{C}^{*}\right. \\
100)\end{array}$ & $\begin{array}{l}\text { All alternative } \\
\text { waters } \\
(\mathrm{W}+\mathrm{P}+\mathrm{Rs}) / \\
\mathrm{C} * 100\end{array}$ \\
\hline Centralized & 52 & 23 & 12 & 107 & 53 & 130 & 195 \\
\hline
\end{tabular}


Table 4: 'Total Use Replaceability'/ Supply Substitution of alternative sources of water including loss in the system for the year 2013-2014

\begin{tabular}{|c|c|c|c|c|c|c|c|}
\hline \multirow{3}{*}{ Supply } & \multirow[b]{2}{*}{$\begin{array}{l}\% \text { of } \\
\text { Total }\end{array}$} & \multicolumn{6}{|c|}{$\%$ of potential replaceability/substitution of water supply } \\
\hline & & Rainwater & $\begin{array}{l}\text { Storm } \\
\text { Water }\end{array}$ & $\begin{array}{l}\text { Waste } \\
\text { Water }\end{array}$ & $\begin{array}{l}\text { Unaccounted } \\
\text { For Water } \\
\text { (UFW)/ } \\
\text { NRW }\end{array}$ & $\begin{array}{l}\text { Wastewater } \\
\text { and } \\
\text { rainwater }\end{array}$ & $\begin{array}{l}\text { All } \\
\text { Alternative } \\
\text { Waters }\end{array}$ \\
\hline & $\begin{array}{l}\overline{C C} \\
\mathrm{C}+\mathrm{D}) * 1 \\
00\end{array}$ & $\begin{array}{l}\mathrm{P} / \\
(\mathrm{C}+\mathrm{D}) * 100\end{array}$ & $\begin{array}{l}\mathrm{R}_{S} / \\
(\mathrm{C}+\mathrm{D})^{*} \\
100\end{array}$ & $\begin{array}{l}\mathrm{W} / \\
(\mathrm{C}+\mathrm{D}) * 100\end{array}$ & $\begin{array}{l}\text { Cufw/ } \\
(\mathrm{C}+\mathrm{D})^{*} 100\end{array}$ & $\begin{array}{l}(\mathrm{W}+\mathrm{P}) / \\
(\mathrm{C}+\mathrm{D}) * 100\end{array}$ & $\begin{array}{l}(\mathrm{W}+\mathrm{P}+\mathrm{Rs}) / \\
\mathrm{C} * 100\end{array}$ \\
\hline Total Use & 100 & 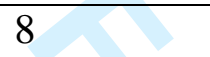 & 6 & 55 & 27 & 63 & 90 \\
\hline
\end{tabular}

A new significant indicator was found for Bangalore city which is derived from system loss and has been termed here as 'Water Loss Recovery'. The 'total use replaceability' potential from 'Water Loss Recovery' was 27\% and centralized replaceability was $53 \%$ shown in table 3 and table 4 which indicates that 179 GL could be used as inputs in the system (table 2). From this and earlier discussions, it is evident that wastewater recycling and improving water efficiency in the water supply network have good potential for augmenting water in the system.

Investigation of roof rainwater harvesting potential in Bangalore city found that out of total rainwater potential, the roof surface available in Bangalore currently can harvest 14 GL annually (BWSSB 2013, Citizen Charter, BWSSB and Rainwater Guidelines BWSSB). If we consider this potential of rainwater, the total potential of roof rainwater harvesting, stormwater and wastewater recycling and loss recovery stands at 550 GL annually or 46 GL monthly or 1.5 GL daily. 
A scenario analysis was done using various water performance indicators and the current and projected water demand of Bangalore city as discussed in supplementary Information. The water demand in Bangalore in 2013 was 1260 million liters per day (MLD); the actual water supply was 927 MLD as found from primary data and thus the actual gap was 815 MLD (considering water received by the end users after system loss). It was found that this gap could easily be met if even $54 \%$ of recycling potential was utilized. The actual water supply in 2014 was 754 MLD (adding 500 MLD Cauvery Stage-IV Phase-II-supply and $53 \%$ UFW) and the actual gap was 675 MLD. This gap could be met if $45 \%$ of recycling potential was utilized. The water demand of Bangalore is expected to rise to 1650 MLD in 2021 as estimated based on Population growth by the census of Bangalore city with the addition of $10 \%$ more slum dwellers and using $120 \mathrm{lpcd}$. The gap between water demand and supply in 2021was calculated as 895 MLD (if present UFW 53\% prevails). This gap can easily be met if $60 \%$ of recycling potential is used.

It was observed that a single source of water such as wastewater or rainwater or stormwater or system loss alone cannot meet the water demand of Bangalore. An integrated management of rainwater, stormwater and wastewater is of utmost importance along with current centralized water supply and system loss recovery is essential. This can avoid import of water from distant river the Cauvery and save energy. Recycling of water can ensure increased water security and reliability, and provide environmental benefits through reduction of water pollution and improvement in ecosystems. 


\title{
Conclusion
}

\author{
Many cities around the world do not have robust accounts of all alternative resources \\ of water in their water systems. The first question of this study was to explore a suitable \\ framework or method to apply in Bangalore city, a rapidly growing developing city which \\ faces serious water stress, to quantify all of its alternative water resources. The refined \\ urban water mass balance framework originally developed by Kenway et al. (2011) was \\ found to be very useful in a developing country context, and could be used also as a \\ physical model (Water Mass Balance Flow Chart in figure S 5). The new addition to the \\ original equation was system loss which is a significant component of water mass balance in \\ a developing country and other water supplies by private retailers, which is common in \\ developing countries. It also included centralized recycled water though it is not common \\ practice in developing countries. Because of a lack of data, decentralized recycled water was \\ assumed 'zero'. The system boundary and the refined framework helped calculate all \\ inflows and outflows within and outside Bangalore city. The high figure of water mass \\ balance may be due to some errors in calculation especially those for quantifying the \\ groundwater recharge value, which can be further studied. Moreover, data on decentralized \\ recycled water can provide more accurate mass balance figure.
}

The second question was to explore how the refined water mass balance equation can improve accounting of all sources of water and help planners, engineers, water managers and policy makers improve the city water performance and management. The analysis found that the wastewater solely had the potential of 362 GL which was enough to replace centralized water supply (338 GL) However, it was found that a single alternative 
source either rainwater or storm water or wastewater has not potential to meet the total water demand in Bangalore city. An integrated water management of all waters sources, including present centralized supply, and improving the efficiency of the water supply network to recover system loss is essential. This can avoid further withdrawal of water from the Cauvery River and reduce the energy cost to provide water services.

The water performance indicators will help engineers and water managers to monitor water performance of Bangalore city and follow various strategies to improve its overall performance over time. The robust accounting followed in this study is not only important for Bangalore but also for other cities especially fast growing cities in developing countries which are facing serious water shortages and moving towards distant river sources or deep aquifers or seawater to meet demand.

For improved results, more accurate data on groundwater infiltration rates and various coefficients based on local situations and decentralized water use from various sources were needed. Further this water mass balance needs to be updated as cities grow both horizontally and vertically with time. 


\section{Acknowledgement}

This study was done by Reba Paul under her joint Master's Program on 'Integrated Water Management' between the University of Queensland, University of Western Australia, Monash University, Griffith University and International Water Centre. The study was funded by International Water Centre in Australia and Global Water Partnership at Stockholm, Sweden. The authors greatly acknowledge the support of Bangalore Water Supply and Sewerage Board (BWSS B) with providing data and information to enable this study especially Mr. S.M. Ravisankar, Former Chairman of BWSSB for his kind cooperation and instruction to the officials in accessing data. The authors provide their sincere gratitude to Dr. P.N. Ravindra, Executive Engineer, BWSSB; Mr. V.C. Kumar, Executive Engineer, BWSSB; Mr. Guru P. Srinath, Technical Assistant to Chief Engineer, Cauvery Division and his assistant or data keeper Mr. Eswara and other officials in BWWSB to make necessary data available for this study. The authors also thank the anonymous reviewers and their feedback particularly Erika Whillas for poof reading of part of the article at some stage and Gautam Joshii for his kind support to facilitate field work in Bangalore. The authors extend hearty thanks to Mr. V. C. Kumar for his kind support to Ms. Paul for her field visit to a number of wastewater treatment plants and access data. The authors finally thank the University of Queensland to use the wonder library facilities to access valuable journals for the study. Dr. Kenway acknowledges DECRA funding DE 160101322. 


\section{References}

Agudelo-Vera, C. M., W. R. Leduc, A. R. Mels, and H. H. M., Rijnaarts. 2012. Harvesting urban resources towards more resilient cities. Resources, Conservation and Recycling 64: $3-12$.

Alberti, M. 1996. Measuring urban sustainability. Environmental impact assessment review 16(4-6):381-424

Baccini, P. and P. H. Brunner. 1991. Metabolism of the Anthroposphere (10-46). Springer Berlin Heidelberg.

Bach, P. M., W. Rauch, P. S. Mikkelsen, D. T. McCarthy, and A. Deletic. 2014. A critical review ofintegrated urban water modelling-Urban drainage and beyond. Environmental Modelling \& Software 54: 88-107

Bai, X. 2007, Industrial Ecology and the Global Impacts of Cities. Journal of Industrial Ecology.

Baker, L. A., D. Hope, Y. Xu, J. Edmonds, and L. Lauver. 2001. Nitrogen balance for the CentralArizona-Phoenix (CAP) ecosystem. Ecosystems 4(6): 582-602.

Barles, S. 2009. Urban metabolism of Paris and its region. Journal of Industrial Ecology, 13(6):898-913

Barrett, J., H. Vallack, A. Jones, and G. Haq. 2002. A material flow analysis and ecological footprint of York. Stockholm, Stockholm Environment Institute.

Bohle, H.G. 1994. Metropolitan food systems in developing countries: The perspective of Urban Metabolism. GeoJournal 34(3):245-251

Browne, D., B. O’Regan, and R. Moles. 2009. Assessment of total urban metabolism and metabolic inefficiency in an Irish city-region. Waste Management 29(10):2765-2771

Center for Science and Environment (CSE). 2011. Water waste Portrait, viewed on 10 November 2013 at http://cseindia.org/userfiles/bangaluru_portrait.pdf.

Chartered Institute of Wastes Management (CIWM). 2002. A Resource Flow and Ecological Footprint Analysis of Greater London. Best Foot Forward, London.

City Development Authority (CDA). 2009. Bangalore Master Plan 2015. Bangalore, India.

Deccan Herald. 2013. Only 44,000 houses in City have RWH. published on 26 Feb. www.deccanherald.com/content/315171/only-44000-houses-city- have.html. Accessed on $3^{\text {rd }}$ April, 2014

Decker, E. H., S. Elliott, F. A. Smith, D. R. Blake, and F. S. Rowland. 2000. Energy and material

This is a proof for the purposes of peer review only. 
flow through the urban ecosystem. Annual review of energy and the environment 25.

Duvigneaud, P., and S. Denayeyer-De Smet. 1977. The urban ecosystem of Brussels.

L'Ecosystéme Urbs, in L'Ecosystéme Urbain Bruxellois, in Productivité en Belgique. In:

Duvigneaud, P., Kestemont, P. (Eds.), Traveaux de la Section Belge du Programme Biologique International Bruxelles 581-597

ETH Globe. 2010. Future Cities. International Edition. Zurich

Færge, J., J. Magid, and F. W. P. de Vries. 2001. Urban nutrient balance for Bangkok. Ecological modelling 139(1): 63-74.

Farooqi, M. A. 2011. Groundwater Management in Bangalore: Impact of Municipal Waste Disposal Practices on Groundwater Quality. Journal of the Geological Society of India 78(5): 488-489

Farooqui, T. A., M. A. Renouf, and S. J. Kenway. 2016. A metabolism perspective on alternative urban water servicing options using water mass balance. Water research 106: 415-428

Gandy, M. 2004. Rethinking urban metabolism: water, space and the modern city. City 8(3), 363-379.

Gasson, B. 2002. The ecological footprint of Cape Town: Unsustainable resource use and planning implications. Paper presented a National Conference of the South African Planning Institution, 18-20 September, Durban, South Africa

Gronwall, J.T., M. Mulenga, and G. McGranahan. 2010. Groundwater, self-supply and poor urban dwellers: A review with case studies of Bangalore and Lusaka.

Human Settlements Working Paper Series, Water and Sanitation 26, International Institute for Environment and Development, London, UK.

Hanya, T. and Y. Ambe. 1976. A Study on the Metabolism of Cities, In: Science for a Better Environment. HSEC, Science Council of Japan, 228-233

Hermanowicz, S.W. and T. Asano. 1999. Abel Wolman's "The Metabolism of Cities" revisited: a case for water recycling and reuse. Water Science and Technology 40(4-5): 29-36

Hegde, G. V. and K.S. Chandra. 2012. Resource availability for water supply to Bangalore city, Karnataka." Current Science (Bangalore) 102(8): 1102-1104.

Hendriks, C., R. Obernosterer, D. Müller, S. Kytzia, P. Baccini, and P. H. Brunner. 2000. Material flow analysis: a tool to support environmental policy decision making. Casestudies on the city of Vienna and the Swiss lowlands. Local Environment 5(3): 311-328.

Holmes, T. and S. Pincetl. 2012. Urban metabolism literature review. Los Angeles, California 
Centre for Sustainable Communities at UCLA.

International Business Machines (IBM). 2010. Rain to Drain: A roadmap to gaining control over water resource management using Information management and predictive analytics. NY, USA.

Kennedy, C., J. Cuddihy, and J. Engel-Yan. 2007. The changing metabolism of cities. Journal of industrial ecology 11(2): 43-59

Kennedy, C., S. Pincetl, and P. Bunje. 2011. The study of urban metabolism and its applications to urban planning and design. Environmental pollution 159(8):19651973.

Kenway, S., A. Gregory and J. McMahon. 2011. Urban water mass balance analysis. Journal of Industrial Ecology 15(5): 693-706.

Kenway, S. J. 2013. The water-energy nexus and urban metabolism-Connections in cities. Brisbane: Urban Water Security Research Alliance.

Kenway, S., J. McMahon, V. Elmer, S. Conrad, and J. Rosenblum. 2013. Managing water-related energy in future cities-a research and policy roadmap. Journal of Water and Climate Change, 4(3), 161-175.

Kingdom, B., R. Liemberger, and P. Marin. 2006. The challenge of reducing non-revenue water $(N R W)$ in developing countries. How the private sector can help: A look at performance-based service contracting. World Bank Group; Water Supply \& Sanitation Sector Board; PPIAF, Discussion Paper Series, 8, Washington DC. USA

Lele, S., V. Srinivasan, P. Jamwal, B.Thomas, M. Eswar, and T. Zuhail. 2013. Water Management in Arkabhaty River: A Situation Analysis, Environment and Development, Working paper No-1, Ashoka Trust for Research in Ecology and the Environment (ATREE), Bangalore, Karnataka, India.

Mitchell, V.G., R. G. Mein, and T. A. McMahon. 2001. Modelling the urban water cycle. Environmental Modelling \& Software 16(7), 615-629

Newcombe, K., J. D. Kalma, and A. R. Aston. 1978. The metabolism of a city: the case of Hong Kong. Ambio 3-15

Newman, P. W. 1999. Sustainability and cities: extending the metabolism model. Landscape and urban planning 44(4): 219-226.

Nilsson, J. 1995. A phosphorus budget for a Swedish municipality. Journal of Environmental Management 45(3): 243-253.

This is a proof for the purposes of peer review only. 
Novotny, V., V. Elmer, H. Furumai, S. Kenway, and O. Phills. 2010, Water and Energy Footprints for sustainable communities, International Water Association. Monteal, Canada.

Mehta, V. K., R. Goswami, E. Kemp-Benedict, S. Muddu, and D. Malghan. 2014. Metabolic urbanism and environmental justice: the water conundrum in Bangalore, India. Environmental Justice, 7(5):130-137

Pincetl, S., P. Bunje, and T. Holmes 2012. An expanded urban metabolism method: Toward a systems approach for assessing urban energy processes and causes. Landscape and urban planning 107(3):193-202.

Raj, K. 2013. Where All the Water has gone? An Analysis of Unreliable Water Supply in

BangaloreCity. Working Paper, Institute of Social and Economic Change (ISEC). Bangalore, India

Rapoport, E. 2011. Interdisciplinary Perspectives on Urban Metabolism. A Review of Literature. UCl Environmental Institute Working Paper. London: University College London, Development Planning Unit.

Renouf, M., S. Kenway, S. Serao-Neumann, and D. Low Choy. 2016. Urban Metabolism for Planning Water Sensitive Cities: Concept for an Urban Water Metabolism Framework. Victoria: Cooperative Research Centre for Water Sensitive Cities.

Sahely, H. R., S. Dudding, and C.A. Kennedy. 2003. Estimating the urban metabolism of Canadian cities: GTA case study. Canadian Journal for Civil Engineering 30: 468-483.

Schulz, N.B. 2007. The direct material inputs into Singapore's development. Journal of Industrial Ecology 11 (2): 117-131.

Stimson, R., J. Western, P. Mullins, and R. Simpson. 1999. Urban metabolism as a framework for investigating quality of life and sustainable development in the Brisbane-Southeast Queensland Metro region. Urban quality of life: Critical issues and options 43-168

The Hindu. 2014. Karnataka resorts to load-shedding. www.thehindu.com/todays paper/tp national/karnataka-resorts-to-loadshedding/article5980608.ece. Accesses May 2014.

The Times of India. 2014. Karnataka to face two-hour long power cuts daily. http://timesofindia.indiatimes.com/city/bengaluru/Karnataka-to-face-two-hour-longpower-cuts-daily/articleshow/34706488.cms?. Accessed on May 2014

Theriault, J. and A.M. Laroche. 2009. Evaluation of the urban hydrologic metabolism of the Greater Moncton region, New Brunswick. Canadian Water Resources Journal 34 (3):255-268. 
United Nations (UN). 2014. World Urbanization Prospects The 2014 Revision Highlights. Economic and Social Affairs, New York, USA

Warren-Rhodes, K. and A. Koenig. 2001. Escalating Trends in the Urban Metabolism of Hong Kong: 1971-1997, AMBIO: A Journal of the Human Environment, 30(7):429-438.

Van Leeuwen, C. J., J. Frijns, A. Van Wezel, and F. H. M. Van De Ven. 2012. City Blueprints: 24Indicators To Assess The Sustainability of The Urban Water Cycle. Water Resources Management, 26, 2177-2197.

Wolman, A. 1965. The metabolism of cities. Scientific American 213(3): 179-190.

World Bank. 2013. Karnataka: Three Towns Pilot 24/7 Water Supply. http://www.worldbank.org/en/news/feature/2013/01/01/karnatak a-three-towns-pilot-water-supply. Accessed April 2014.

Zhang, Y. and Z. Yang. 2007. Eco-efficiency of urban material metabolism: a case study in Shenzhen, China. Acta Ecologica Sinica 27 (8): 3124-3131.

Zucchetto, J. 1975. Energy, economic theory and mathematical models for combining the systems of man and nature. Case study, the urban region of Miami. Ecological Modelling 1, 241-268 


\begin{abstract}
About the Authors
1. Reba Paul was a Masters Student at University of Queensland, Australia when the article was written. Now she is a PhD Student and Research Assistant at Institute for Sustainable Futures (ISF) in the University of Technology Sydney (UTS), Australia.

2. Steven Kenway is an Associate Professor and Research Group Leader for Water-EnergyCarbon Group at School of Chemical Engineering in University of Queensland (UQ), Brisbane, Australia.
\end{abstract}

3. Brian McIntosh is an Education Director at International Water Centre (IWC) and Senior Lecturer at University of Queensland (UQ), Brisbane, Australia.

4. Pierre Mukheibir is an Associate Professor and Research Director at Institute for Sustainable Futures (ISF) in the University of Technology Sydney (UTS), Australia

This is a proof for the purposes of peer review only. 
1

2

3

4

5

6

7

8

9

\section{Supplementary Information}

\section{Urban Metabolism of Bangalore City: A Water Mass Balance Analysis}

Reba Paul ${ }^{1}$, Steven Kenway ${ }^{2}$, Brian McIntosh ${ }^{3}$ and Pierre Mukheibir ${ }^{4}$

\section{Address correspondence to:}

Reba Paul

Doctoral Researcher and Research Assistant

Institute for Sustainable Futures (ISF)

University of Technology Sydney

Level 11, Building 10

235 Jones Street, Ultimo NSW 2007

Email: reba.paul@uts.edu.au 


\section{Summary}

This document discusses 1) system and sub-systems boundaries how those were selected 2) all primary and secondary data collected and how those interpreted and used for water mass balance analysis 3) water mass balance analysis of Bangalore city (can be interpreted as a physical model) 4) various performance indicators to monitor metabolic performances of Bangalore city and 5) a scenario analysis presenting the future challenges of Bangalore city in respect of water demand and supply and how those can be met from harnessing alternative sources of water and stop for further withdrawal of water from the Cauvery river which involves more than $60 \%$ of their annual operating budget (CSE 2011; IBM 2010 and BWSSB 2014) for energy.

\section{Selection of System boundary and Boundaries and data collection}

\section{System Boundary}

Identifying a 'system boundary' was very important to include all water data in a system (both inputs and outputs). A large city usually has three to four different boundaries - a) the core city or area, b) the built up area adjacent to the core area, c) the metropolitan area, and d) extended planning region (Satterthwaite 2008 and Kenway 2013). In this research, the core city and adjacent built up are (BWSSB service area) shown in figure S1 has been considered as the system boundary. The system boundary was taken as the service area of Bangalore Water Supply and Sewerage Board (BWSSB) which is 800 sq.km (BWSSB 2013). 


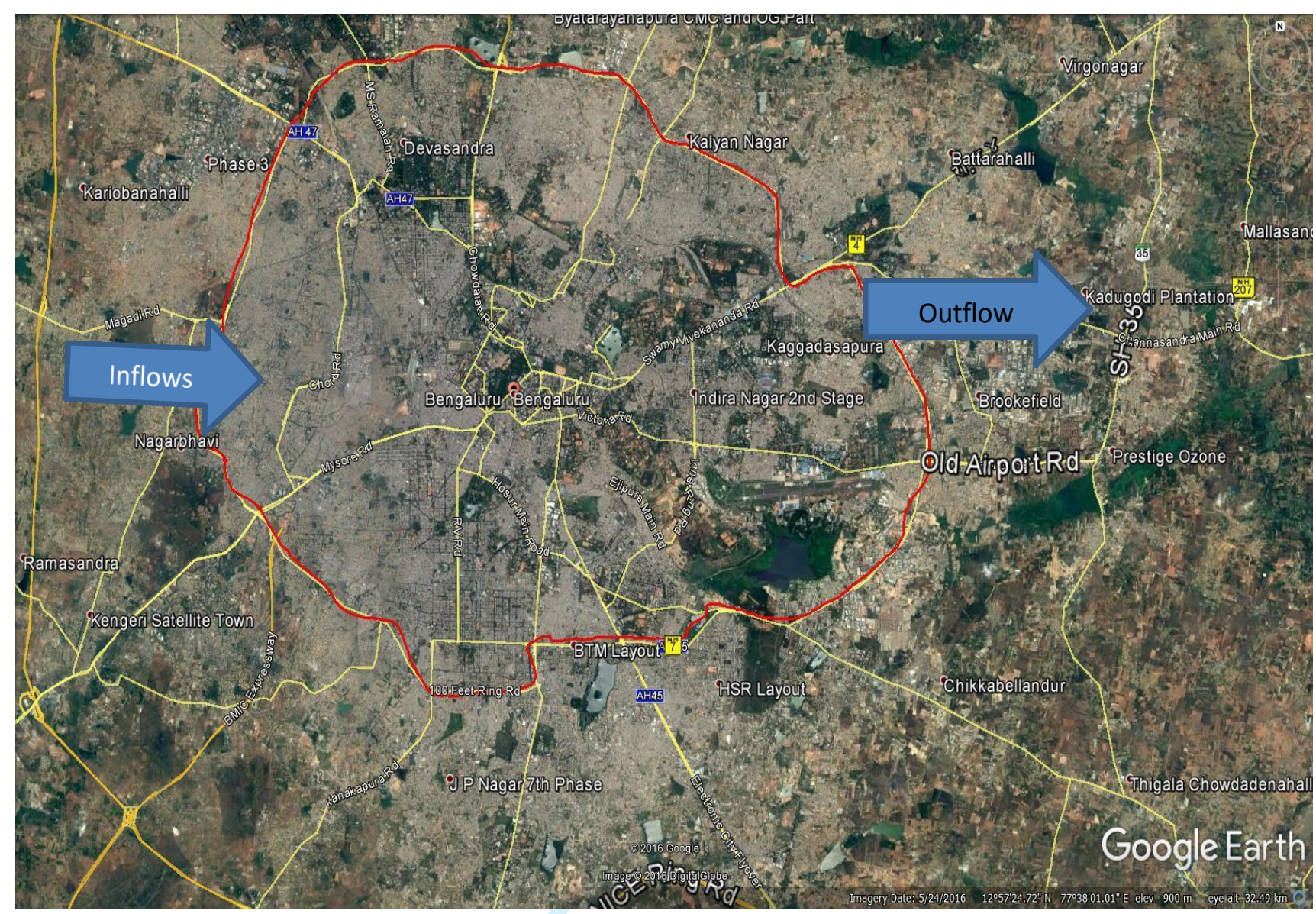

Figure S 1: System Boundary for Water Mass Balance Analysis for Bangalore city (BWSSB 2013) (Bangalore Water Supply and Sewerage Board Service Area (800 sq. km) showing various features such as building, open space, green space, transport network (considered as system boundary with $1 \mathrm{~km}$ under the ground level) (Sources: Google Earth)

\section{Sub-system boundaries and their areas}

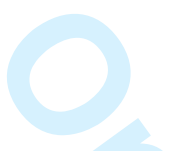

The sub-system boundaries within system boundary were taken as Water Treatment

Plants (WTPs), Wastewater Treatment Plants (WWTPs), various sub-sectors such as residential, commercial, industrial, public and semi-public institutions, parks and open space, transport and communication, agriculture, lakes and ponds. The subsystem boundary areas and their percentages against system boundary have been calculated in table S1 based on land use in Bangalore city in table S3 and System Boundary (figure S1). These values were used for calculation for sub-boundary precipitation, runoff and groundwater recharge.

Assumptions: The areas of WTPs and WWTPs were assumed minimal or zero compared to areas of other sub-systems. 
Table S 1: Sub-systems boundaries and their areas

\begin{tabular}{lrc}
\hline Land Use & Area (sq.km) & Distribution (\%) \\
Residential & 243.7 & 30.5 \\
Commercial & 16.4 & 2.0 \\
Industrial & 38.4 & 4.8 \\
Institutional and Public & 166.0 & 20.7 \\
Transport and & 117.0 & 14.7 \\
Open and green space & 100.0 & 12.5 \\
Tank and lakes & 39.2 & 4.8 \\
Agricultural areas & 117.6 & 14.7 \\
Total & 800 & 100 \\
Source: CDA 2009 and BDA 2011 & &
\end{tabular}

\section{Organizations responsible for water supply and sewerage services}

The water cycle in Bangalore is managed by various organisations such as BWSSB (responsible for water supply and sewerage), CGWB (groundwater monitoring and management), BBMP (Bruhut, Bangalore, Mahanagar, Pallika (stormwater drainage and solid waste management), Bangalore Development Authority (BDA) (city planning), private water suppliers (sell water) and self-suppliers with overlapping responsibilities and there is no central water database for water. This makes measuring of various inputs and outputs a challenging task (BWSSB 2013; CGWB 2009; Department of Water Resources 2011; GEC 1997; CGWB 2009).

\section{Population and percentage of built up area in Bangalore over last 40 years}

The evaluation of density of population and Percentage of built-up (concrete) Area in Bangalore in last 40 years is shown in table S2. BWSSB 2013 and Hedge and Subhash 2012 report that due to rapid urbanization, most rainfall, over $90 \%$, flows to lakes and open water bodies with groundwater recharge being reduced to $5 \%$ or even less. Due to decreased vegetation, evapotranspiration has also decreased to $5 \%$ or even less. 
As per Census of India (2011) the growth rate during 2001-2011 was of 47.2\% (Census of India 2011). The population of the BWSSB service area $\left(800.29 \mathrm{~km}^{2}\right)$ was 8.5 million in 2011 and 5.7 million in 2001 (Census 2001 and census 2011). The total population figure includes a 10\% urban slum population (KSCB 1999 and Mallick 2009) but actual slum population is an urban agglomeration ${ }^{1}$. About $90.94 \%$ of people live in the city core/municipal area and only 9.06\% live in rural areas (Census of India 2011). Considering the growth rate $47.2 \%$ over 20012011, the total population in Bangalore service area in 2013-2014 can be calculated as 9.5 million and in 2014 is 10 million (indianonlinepages 2014). Assuming the same growth rate and including all slum population, the population of Bangalore city can reach 12.5 million by 2021 .

Precipitation/Rainfall (P) BWSSB 2013 and Hedge 2012 report that due to rapid urbanization, most rainfall, over 90\%, flows to lakes and open water bodies with groundwater recharge being reduced to $5 \%$ or even less. Due to decreased vegetation, evapotranspiration has also decreased to $5 \%$ or even less.

Bangalore has a dry and tropical climate with four seasons. The city receives an average annual rainfall of 830-970 mm. The average annual rainfall over the past 100 years was $972 \mathrm{~mm}$ (BWSSB 2013 and Meteorological Centre Bangalore 2014). Climate change however can affect average annual

\footnotetext{
${ }^{1}$ Urban agglomeration is knows as an extended city/town area consisting of the built-up area of a central core of city (in this case core area is $\mathrm{BMP} /$ municipal area) and any district or suburbs linked by continuous urban area (ULB and 110 villages). 
precipitation and actual evapotranspiration with extreme drought and flood (Grownwall 2008 and IIHS 2014). Rainfall in Bangalore is irregular but sometime causes urban floods especially during monsoons (June-November) (IIHS 2012). Bangalore experiences flood from heavy rainfall (IIFS 2014). The monthly rainfall varies and number of rainy days are 60 (Vishwanath 2012, BWSSB 2013 and Meteorological Centre Bangalore 2014.). Large parts of Bangalore are characterized by undulating terrain having a natural gradient with low hills and a number of valleys (Gronwall 2008).

\section{Land Use in Bangalore City}

The land use data in Bangalore city was taken from Bangalore Master Plan 2015 (CDA 2009) which is mentioned in table S3.

Table S 3: Land Use in Bangalore City

\begin{tabular}{|c|c|c|c|c|}
\hline Land Use & $\begin{array}{c}\text { Land use } \\
(2011)^{1} \text { (sq.km) }\end{array}$ & $\begin{array}{l}\text { Distribution } \\
(\%)\end{array}$ & $\begin{array}{l}\text { Land use } \\
\text { in } 2003 \\
(\mathrm{sq} . \mathrm{km})\end{array}$ & $\begin{array}{l}\text { Distribution } \\
\%\end{array}$ \\
\hline Residential & 243.7 & 43.2 & 159.8 & 37.9 \\
\hline Commercial & 16.4 & 2.9 & 12.8 & 3.0 \\
\hline Industrial & 38.4 & 6.8 & 58.8 & 13.9 \\
\hline \multicolumn{5}{|l|}{ Public: } \\
\hline Open space & 77.9 & 13.8 & 13.1 & 3.1 \\
\hline $\begin{array}{l}\text { Public and semi- } \\
\text { public uses }\end{array}$ & 49.1 & 8.7 & 46.6 & 11.0 \\
\hline Public Utilities & & 0 & 2.5 & 0.6 \\
\hline $\begin{array}{l}\text { Offices and } \\
\text { services }\end{array}$ & & 0 & 4.3 & 1.0 \\
\hline $\begin{array}{l}\text { Transport and } \\
\text { communication }\end{array}$ & 116.9 & 20.7 & 88.3 & 20.9 \\
\hline Unclassified & 22.2 & 3.9 & 35.3 & 8.4 \\
\hline Total & 564.6 & 100 & 421.4 & 100 \\
\hline Agriculture & & & 649.3 & \\
\hline Lake and tank & & & 39.0 & \\
\hline Quarry & & & 9.6 & \\
\hline Vacant & & & 187.7 & \\
\hline Grand Total & & & 1307 & \\
\hline
\end{tabular}

Sources: CDA 2009 


\section{Centralized Raw Water and Treated Water Supply $\left(C_{\text {raw }}\right.$ and C)}

The centralized water supply for Bangalore over 12 months for 2013-2014 was collected from the Cauvery Water Division of BWSSB to get the daily average centralized water supply.

The average supply during 2013-2014 was 977 MLD. Figure S2 shows variation in average daily water withdrawal and its variation over various months. Figure-3 shows the daily treated water supply during 2013-2014, the average of which 927 MLD.

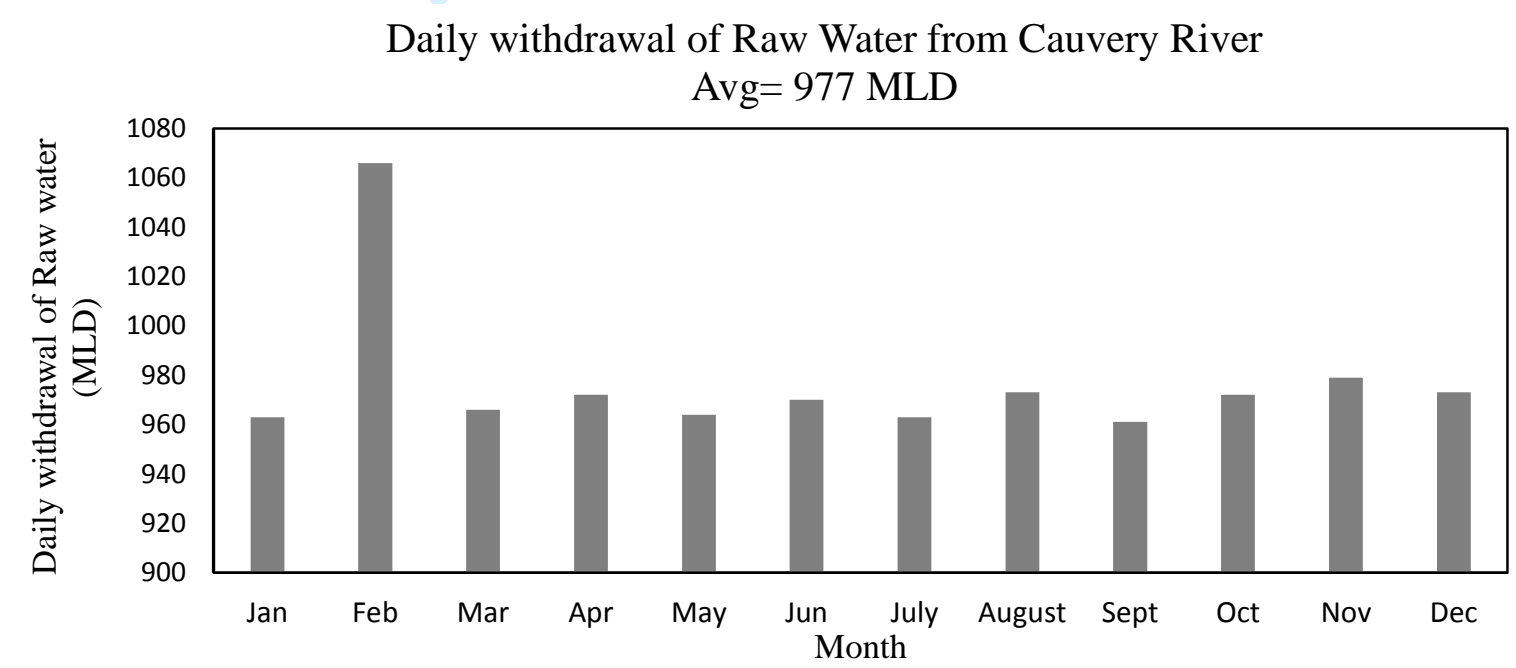

Figure S 2: Raw water withdrawn from the Cauvery during 2013-2014

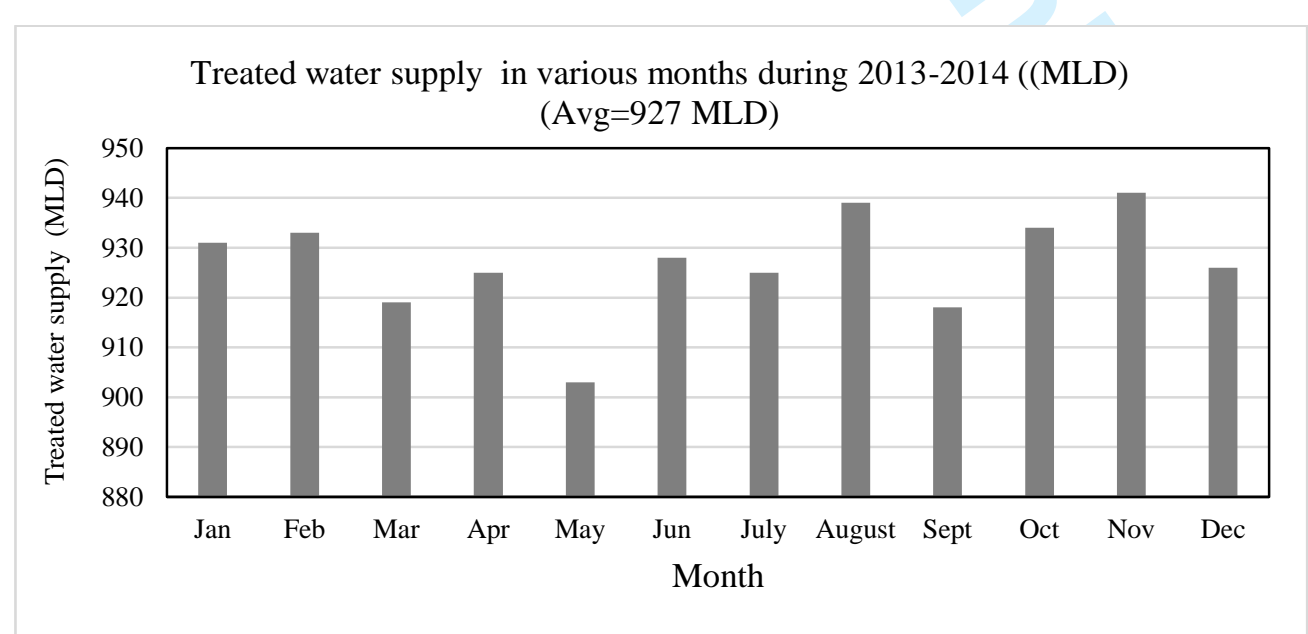

Figure S 3: Daily water supply to the city at various months during 2013-2014

The primary data shows that there is variation in data found from various technical 
reports of BWSSB. In 2013 the average water supply was 927 MLD against reported value 1,260 MLD (Raju 2014). This may be Cauvery supply from stage-IV (Phase -II) 500 MLD was not added in that year (the project was supposed to finish in that year).

\section{Decentralized Groundwater Supply (Dg) and Surface water supply Ds}

There is no accurate information on groundwater use Dg and the total figure could not be collected from any agencies in Bangalore such as CGWB, BWSSB. The related data was however found in some secondary sources as mentioned in table S4 (IIHS 2012). The decentralized surface water supply Ds was also found in the same source (table S4).

Table S 4: Decentralized Groundwater and Surface Water Use by retailers in Bangalore

\begin{tabular}{lccccc}
\hline & \multicolumn{5}{c}{ Decentralized Water Supply (MLD) } \\
\cline { 2 - 6 } & $\begin{array}{c}\text { BWSSB } \\
\text { registered } \\
\text { private tube } \\
\text { wells }\end{array}$ & $\begin{array}{c}\text { Private } \\
\text { Tankers }\end{array}$ & $\begin{array}{c}\text { Self-supply } \\
\text { by } \\
\text { households }\end{array}$ & $\begin{array}{c}\text { Self-supply } \\
\text { by others }\end{array}$ & Total use \\
\hline Groundwater & 200 & 162 & 261 & 167 & 790 \\
\hline Surface Water & - & 65 & - & - & 65 \\
\hline
\end{tabular}

Source: IISC 2012

\section{Decentralized Rainwater Supply (Dr)}

In the current context of Bangalore, it is difficult to calculate decentralized rainwater as data is not available. It was found from various sources that so far 44,000 houses in Bangalore have installed rainwater tank systems and they are also recharging groundwater from rainwater in addition to using it for non-potable purposes (FirstPost 2013, Citizen Matters 2013; Deccan Herald 2013 and The Hindu 2013). No data is available on how many rainwater plants have been constructed in residential, commercial, industrial and other areas (BWSSB 2013; Vishawnath 2012; Vishawnath 2001).

In 2009, Bangalore amended the Bangalore Water Supply and Sewage Act to modify Bangalore Rainwater Harvesting Regulations (BWSSB 2014; BWSSB 2014a). It is now 
obligatory that every house owner install rainwater tanks or harvesting structures in all old buildings with a built-up area of 2,400 square feet (sq $\mathrm{ft}-40^{\prime} \times 60^{\prime}$ or $12 \mathrm{~m} \times 20 \mathrm{~m}$ ) and future buildings of $1,200 \mathrm{sq} \mathrm{ft}\left(30^{\prime} \times 40^{\prime}\right.$ or $\left.10 \mathrm{~m} \times 12 \mathrm{~m}\right)$ (BWSSB 2013).

Assuming that 44000 properties harvest rainwater (Deccan Herald 2013) on an average area of $(120+240 \mathrm{sq} \mathrm{ft}) / 2 \sim 200 \mathrm{sq} . \mathrm{m}$ each, a rough estimate of rainwater use has been calculated. Rainwater harvesting potential $=970 \mathrm{~mm} \times 200 \mathrm{~m}^{2} \times 0.9 \times 44,000=0.0077 \mathrm{GL}$ Where roof runoff coefficient is 0.9 .

Assuming 50\% of this is stored and 50\% is used for groundwater recharge, the rainwater use by households or properties is $0.0039 \mathrm{GL} \sim 0.004 \mathrm{GL}$ and groundwater recharge is also 0.004 GL. The city is harvesting a very little amount of rainfall and therefore if the data varies to some extent, it will have insignificant impact of Mass balance calculation.

\section{Groundwater Recharge (G)}

It is also difficult to estimate the groundwater recharge due to unavailability of continuous water table monitoring data in Bangalore. But as per the detailed Guidelines for Implementing Groundwater Estimation Methodology (CGWB 2009; CGWB 2011; CGWB 2013) and the Groundwater Resource Estimation Methodology (GEM) Report -1997 (MoWR 2009) recommended by Groundwater Resource Estimation Committee (MoWR 2009), the groundwater recharge based on the groundwater fluctuation approach for granite terrain (as in Bangalore) is estimated as $8.7 \%$ of rainfall (GEC 1997). But according to BWSSB, the groundwater recharge in Bangalore has reduced to 5\% (BWSSB 2013). The rainfall infiltration in built up or concrete areas and asphalt roads, can be assumed as zero but still there must be some open areas in between the built up areas. So the groundwater 
recharge in built up area in this study, has been considered as $2 \%$ and in open area or green space, a higher value of 6\% (in between 5\% and 8.7\%) (Hedge and Subhash 2012).

Bangalore has about $39.2 \mathrm{sq}$. $\mathrm{km}$ of water bodies. This value has been used for this study (table S2) (CSE 2011; Ramachandra and Kumar 2008). The recharge rate from water bodies has been considered as 50\% (MoWR 2009 and GEC1997).

Precipitation, runoff, groundwater recharge and evaporation from WTPs and WWTPs have been taken negligible.

\section{Runoff $($ Rs $)$}

The runoff coefficient for various land use (table S5) have been used for this study based on the typical values of runoff coefficient in an urban area as elaborated in Chapter11 of the Urban Drainage Book (Butler and Davies 2011).

Table S 5: Runoff Coefficient used for Bangalore

\begin{tabular}{lc}
\hline Land Type & Runoff Coefficient \\
\hline Residential & 0.5 \\
Commercial & 0.8 \\
Industrial & 0.7 \\
Open Space and Garden/Park & 0.2 \\
Transport (concrete Paving and & 0.9 \\
asphalt) & \\
Agriculture and Vacant Land & 0.07 \\
\hline
\end{tabular}

Source: Butler and Davies 2011

Precipitation, runoff, groundwater recharge and evaporation from WTPs and WWTPs have been taken negligible. 


\section{Evapotranspiration (ET)}

Evapotranspiration for sub-boundaries has been calculated with the following formula from respective values:

$\mathrm{ET}=\mathrm{P}-\mathrm{R}-\mathrm{G}$

\section{The Centralized Water Distribution in Various Subsectors}

The centralized water supply in various subsectors as mentioned in table S6 and graphically shown in figure-S4 has been calculated based on percentage distribution of the total centralized water as collected from BWSSB's Maintenance Division.

Table S 6: Distribution of centralized water supply in 2013-2014

\begin{tabular}{lcc}
\hline Subsectors & $\begin{array}{c}\text { Monthly Water } \\
\text { Consumption } \\
\text { (MLD) }\end{array}$ & $\begin{array}{c}\text { Percentage } \\
(\%)\end{array}$ \\
\hline Residential & 14169 & $36.8 \%$ \\
Commercial & 1343 & $3.5 \%$ \\
Public and semi-public & 1893 & $4.9 \%$ \\
Institutions & & \\
Industries & 514 & 1.3 \\
Open and Green space & 260 & $0.7 \%$ \\
Unaccounted for Water (UFW) & 20322 & $52.8 \%$ \\
\hline
\end{tabular}

Source: BWSSB (primary data) 
Centralized supply distribution in various sub-sectors in (\%)

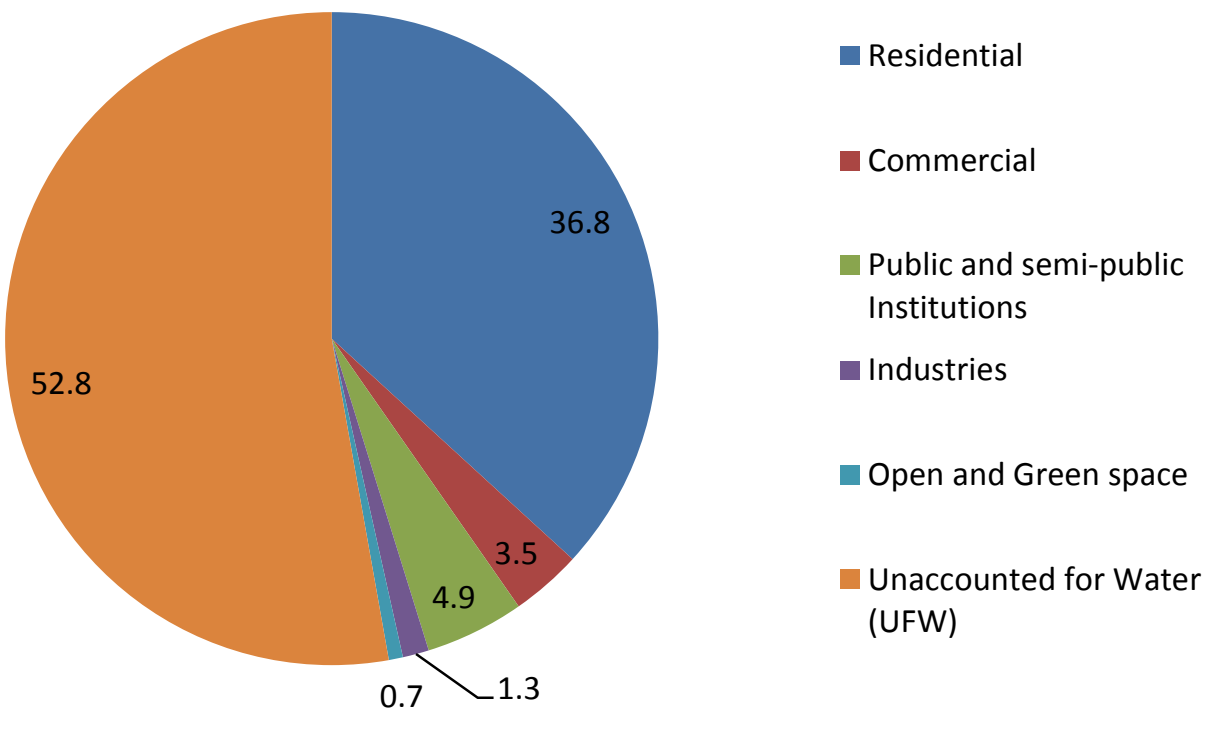

Figure S 4: Centralized water supply distribution in various subsectors and Unaccounted for Water (UFW)/Non-Revenue Water (NRW)

\section{Wastewater flows}

From secondary sources it was sound that Bangalore city generates about 1,000 MLD of wastewater daily (BWSSB 2014). To date, the BWSSB has installed 14 wastewater treatment plants (WWTPs) (10 secondary and four tertiary), the total capacity of which is 721 MLD (Kumar 2013 and BWSSB 2014). The four tertiary treatment plants can produce 73 MLD of recycled water. Treated water so far has only been used for industrial purposes and to a very limited extent (Kumar 2013 and Ravindra 2013). Secondary WWTPs usually use Activated Sludge and tertiary WWTPs use Trickling Filters.

From primary data it was found that Bangalore can treat a total of 525 MLD out of which 65 MLD is treated up to tertiary level. Bangalore can sell 8 MLD out of this 65 MLD highly treated wastewater and other they discharge to open water bodies as reaching this treated water back to city which is far from wastewater treatment plant is very expensive. Out of 1000 MLD generated wastewater, 475 MLD found as not treated. These data were used for mass balance 
analysis.

\section{Water Mass Balance Analysis}

Using various data, all inflows and outflows in the systems and sub-systems were calculated in Gigalitres (GL) yearly for the year 2013-2014 and have been represented in the flow chart in figure-5. The water mass balance was calculated using the following equation.

$$
\begin{aligned}
& \Delta \mathrm{S}=\text { all inflows }- \text { all outflows } \\
& \mathrm{S}=\sum \mathrm{Qi}-\sum \mathrm{Qo}=\left(\mathrm{P}+\mathrm{C}_{\mathrm{raw}}+\mathrm{D}_{\mathrm{r}}+\mathrm{Dg}+\mathrm{Ds}+\mathrm{Rw}\right)-(\mathrm{W} \text { t }+\mathrm{Wpt}+\mathrm{Wtu}+\mathrm{G}+\mathrm{Rs}+\mathrm{ET}+\mathrm{Cufw})
\end{aligned}
$$




\section{$\mathrm{P}=77.6 \mathrm{GL}$}

Craw $=356.3 \mathrm{GL}$

$\mathrm{D}_{\mathrm{r}}=0.004 \mathrm{GL}$

$\mathrm{D}_{\mathrm{g}}=288.4 \mathrm{GL}$

$\mathrm{Ds}=23.7 \mathrm{GL}$

10

13 |

14

15

16

17

Natural Flow

Anthropogenic flow

Self supply by others $(60.96 \mathrm{GL})=288.39$

$\mathrm{Ds}=23.73 \mathrm{GL}$

$\mathrm{D}=\mathrm{D}_{\mathrm{r}}+\mathrm{D}_{\mathrm{g}}+\mathrm{D}_{\mathrm{s}}+\mathrm{R}_{\mathrm{w}}$

\section{Proofs} $\longrightarrow$

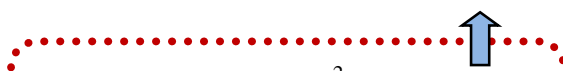

Residential $\left(243.7 \mathrm{~km}^{2}\right)$

$\mathrm{C}_{\mathrm{r}}=124.5 \mathrm{GL}, \mathrm{ET}_{\mathrm{r}}=11.4 \mathrm{GL}$

$\mathrm{Gr}=0.5 \mathrm{GL}, \mathrm{Rsr}=11.8 \mathrm{GL}, \mathrm{D}_{\mathrm{r} / \mathrm{g}}, \mathrm{D}_{\mathrm{r} / \mathrm{r}}$

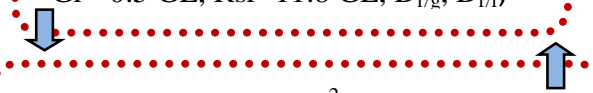

Commercial $\left(16.43 \mathrm{~km}^{2}\right)$

$\mathrm{C}_{\mathrm{c}}=11.84 \mathrm{GL},{ }_{\mathrm{r}}, \mathrm{ET}_{\mathrm{c}}=0.3 \mathrm{GL}, \mathrm{Gc}=0.03 \mathrm{GL}$,

$\mathrm{Rsc}=1.3 \mathrm{GL}, \mathrm{D}_{c / r} \mathrm{D}_{c / s}$

0.00000000

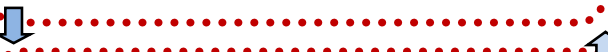

Industrial

$\mathrm{C}_{\mathrm{i}}=4.4 \mathrm{GL}, \mathrm{ET}_{\mathrm{i}}=1.0 \mathrm{GL}, \mathrm{Gi}=0.07 \mathrm{GL}$

$\mathrm{Rsi}=2.6 \mathrm{GL}, \mathrm{D}_{\mathrm{i} / \mathrm{r}}, \mathrm{D}_{\mathrm{i} / \mathrm{g}}$,

ת,

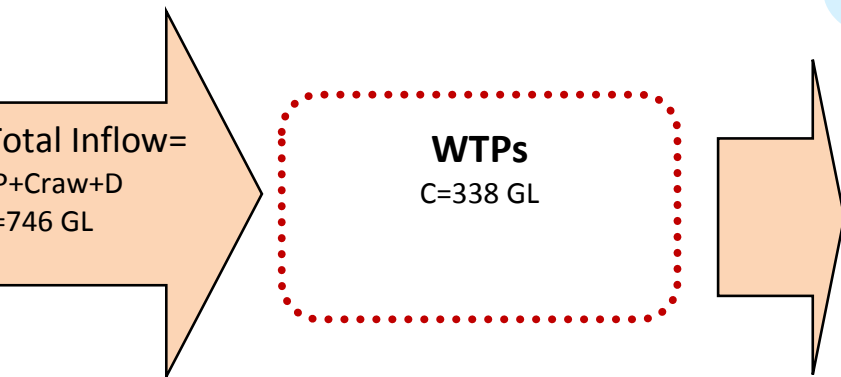

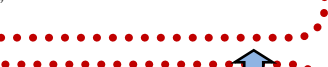

Open and Green Space $\left(100 \mathrm{~km}^{2}\right)$ $\mathrm{Co}=2.4 \mathrm{GL}, \mathrm{ETo}=7.2 \mathrm{GL}, \mathrm{Go}=0.6 \mathrm{GL}$ $\mathrm{Ro}=2.0 \mathrm{GL}, \mathrm{Do} / \mathrm{r}, \mathrm{D}_{\mathrm{o} / \mathrm{g}}$$$
\text { ? }
$$

Public/Semi-Public Area $\left(166 \mathrm{~km}^{2}\right)$
$\vdots$
$\mathrm{C}_{\mathrm{ps}}=16.6 \mathrm{GL}, \mathrm{ET} \mathrm{ps}=4.5 \mathrm{GL}, \mathrm{Gps}=0.3 \mathrm{GL}$,
$\mathrm{Rps}=11.3 \mathrm{GL}, \mathrm{D}_{\mathrm{ps} / \mathrm{r}}, \mathrm{Dps}_{\mathrm{g} / \mathrm{g}}$

$\mathrm{Rw}=2.9$

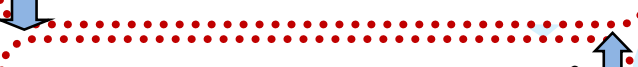

System Boundary (BWSSB Service Area 800 sq.km)

Transport and Comm $\left(116.97 \mathrm{~km}^{2}\right)$

ETtc $=0.9$ GL, Gtc $=0.23$ GL, Rtc $=10.2$

Sub-system Boundary (as mentioned in chart)

$\mathrm{D}_{\mathrm{g}}=$ Utility registered supply $(73 \mathrm{GL})+$ Private Tankers

$(59.13 \mathrm{GL})+$ Self supply by households $(95.3 \mathrm{GL})+$

GL,

$\mathrm{nto} / \mathrm{s} \mathrm{Ctr}-\mathrm{n}$

\section{Agriculture Area $\left(117.64 \mathrm{~km}^{2}\right)$}

$\mathrm{ET}_{\mathrm{ag}}=10 \mathrm{GL}, \mathrm{Gag}=0.7 \mathrm{GL}, \mathrm{Rag}=0.8 \mathrm{GL}$ $\mathrm{Dag} / \mathrm{r} \mathrm{Dag} / \mathrm{g}, \mathrm{Cag}=0$

.

\section{Lakes and Ponds Area $\left(39.2 \mathrm{~km}^{2}\right)$} $\mathrm{ET}_{\mathrm{L}}=2 \mathrm{GL}, \mathrm{GL}=2 \mathrm{GL}, \mathrm{CL}_{\mathrm{L}}=0$ :

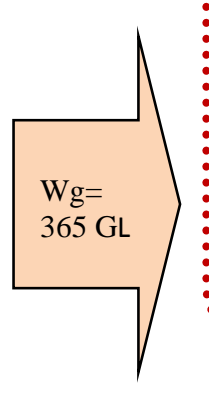

$\mathrm{ET}=\mathrm{ET}_{\mathrm{s}}+\mathrm{ET}_{\mathrm{c}}+\mathrm{ET}_{\mathrm{i}}+\mathrm{ETp}+\mathrm{ET}_{\mathrm{t}}+\mathrm{ET}_{\mathrm{ag}}+\mathrm{ET}_{\mathrm{l}}=33.28 \mathrm{GL}$

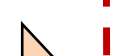
I :

$\mathrm{W}_{\mathrm{nt}}=171 \mathrm{GL}$

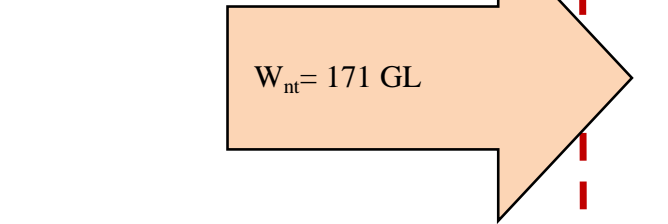

\section{WWTPs}

$\mathrm{Wit}_{\mathrm{it}}=193.7 \mathrm{GL}$

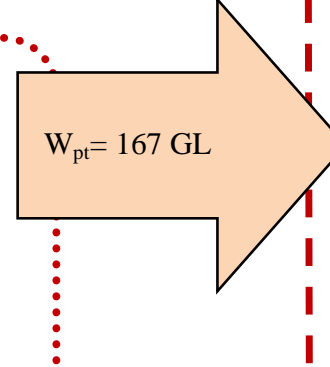

Unused treated $\mathrm{W}_{\mathrm{tu}}=23.7 \mathrm{GL}$

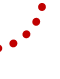

$\mathrm{Rs}=40 \mathrm{GL}$

Total wastewater flow

$\mathrm{Wr}=\mathrm{W}_{\mathrm{nt}}+\mathrm{W}_{\mathrm{pt}}+\mathrm{W}_{\mathrm{tu}}=362 \mathrm{GL}$

$\mathrm{G}=\mathrm{Gr}+\mathrm{Gc}+\mathrm{Gi}+\mathrm{Gp}+\mathrm{Gt}+\mathrm{Go}+\mathrm{Gag}+\mathrm{GL}=4.4 \mathrm{GL}$

Cufw $=178.6 \mathrm{GL}$

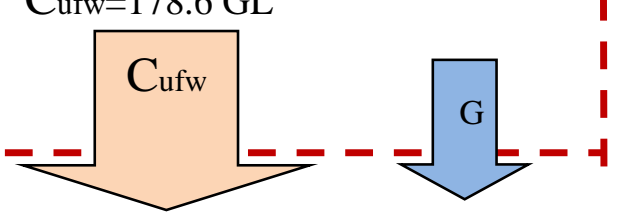

igure S 5: Water Mass Balance Flow Chart of Bangaloreccity for the year 2013-2014 


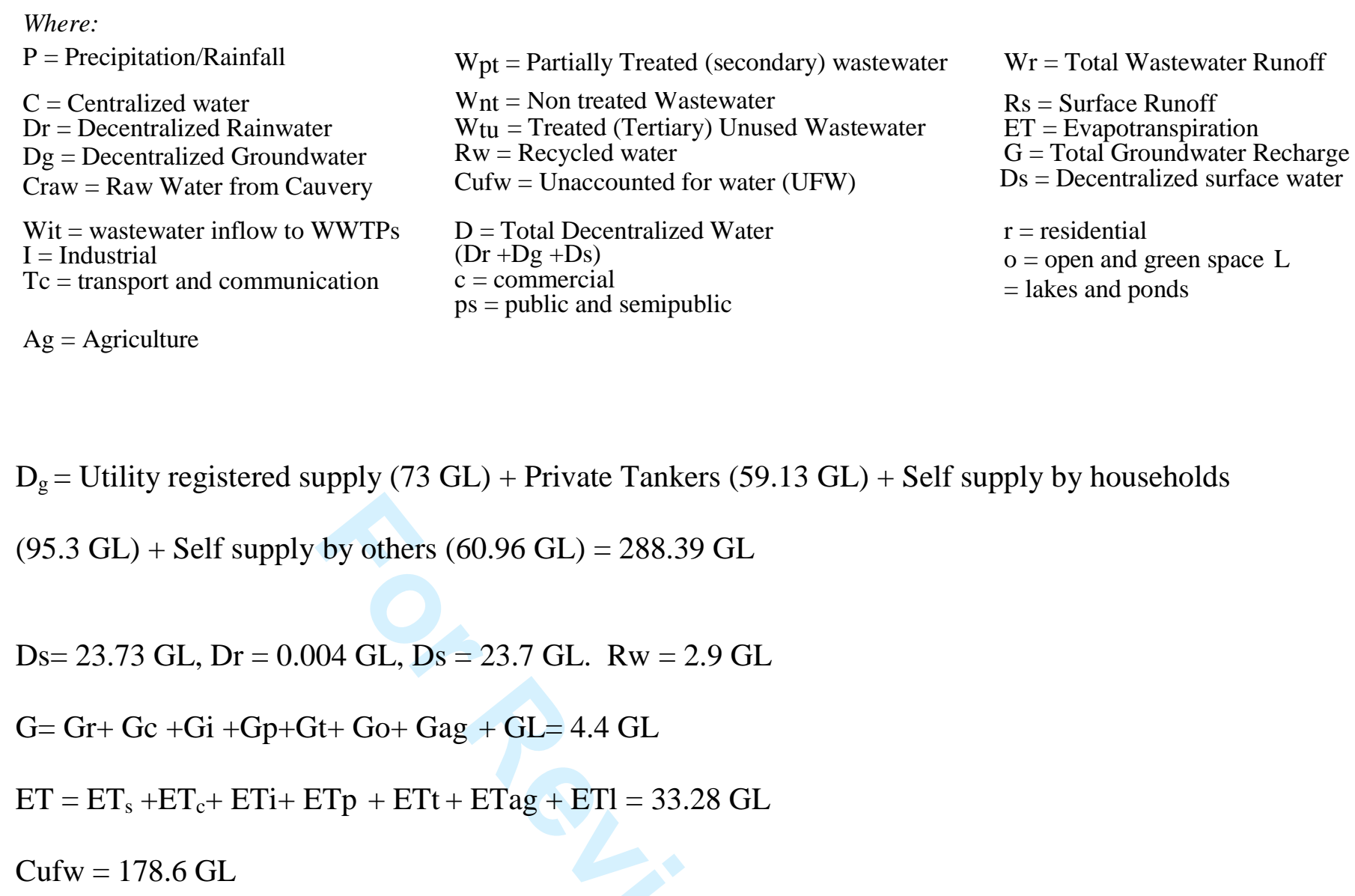

$\mathrm{Ag}=$ Agriculture

$\mathrm{D}_{\mathrm{g}}=$ Utility registered supply $(73 \mathrm{GL})+$ Private Tankers $(59.13 \mathrm{GL})+$ Self supply by households

$(95.3 \mathrm{GL})+$ Self supply by others $(60.96 \mathrm{GL})=288.39 \mathrm{GL}$

$\mathrm{Ds}=23.73 \mathrm{GL}, \mathrm{Dr}=0.004 \mathrm{GL}, \mathrm{Ds}=23.7 \mathrm{GL} . \mathrm{Rw}=2.9 \mathrm{GL}$

$\mathrm{G}=\mathrm{Gr}+\mathrm{Gc}+\mathrm{Gi}+\mathrm{Gp}+\mathrm{Gt}+\mathrm{Go}+\mathrm{Gag}+\mathrm{GL}=4.4 \mathrm{GL}$

$\mathrm{ET}=\mathrm{ET}_{\mathrm{s}}+\mathrm{ET}_{\mathrm{c}}+\mathrm{ETi}+\mathrm{ETp}+\mathrm{ETt}+\mathrm{ETag}+\mathrm{ETl}=33.28 \mathrm{GL}$

$\mathrm{Cufw}=178.6 \mathrm{GL}$

Total wastewater flow $=\mathrm{Wr}=\mathrm{W}_{\mathrm{nt}}+\mathrm{W}_{\mathrm{pt}}+\mathrm{W}_{\mathrm{tu}}=362 \mathrm{GL}$

Using equation - (1), the Water Mass Balance of Bangalore city for 2013-2014 can be calculated as follows:

$\mathrm{S}=\sum \mathrm{Qi}-\sum \mathrm{Qo}=\left(\mathrm{P}+\mathrm{C}_{\mathrm{raw}}+\mathrm{D}_{\mathrm{r}}+\mathrm{Dg}+\mathrm{Ds}+\mathrm{Rw}\right)-(\mathrm{Wnt}+\mathrm{W} \mathrm{pt}+\mathrm{Wtu}+\mathrm{G}+\mathrm{Rs}+\mathrm{ET}+\mathrm{Cufw})$

$S=(77.6+356.3+0.004+288.4+23.73+2.9)-(171+167+23.7+4.4+40+33.28+178.6)$

$=(749-618)$

$=131 \mathrm{GL}$

One Gigaliter GL) $=10^{9}$ liters $(\mathrm{L}) \approx 2.64 \times 10^{8}$ gallons $($ gal $)$

This is a proof for the purplobses of peer review only. 


\section{Water Mass Balance Indicators}

$C=338 \mathrm{GL}$

$D_{r}=0.004 \mathrm{GL}$

Total water use $\mathrm{T}=\mathrm{C}+\mathrm{D}=338+312=653 \mathrm{GL}$

$P=77.6 \mathrm{GL}$,

Rs $=40 \mathrm{GL}$,

$\mathrm{Wr}=362 \mathrm{GL}$

$\mathrm{Rs}=40 \mathrm{GL}$

Cufw $=178.6 \mathrm{GL}$

Using Water Mass Balance Indicators as discussed in the Main article water replaceability potentials were calculated below in table $\mathrm{S} 7$.

This is a proof for the purpldeses of peer review only. 
Table S 7: Water Replaceability Calculation

\begin{tabular}{|c|c|c|c|c|c|c|c|c|c|}
\hline $\begin{array}{l}\text { Supply } \\
\text { Centralization } \\
\text { C/T } \\
(\%)\end{array}$ & $\begin{array}{l}\text { Rainfall } \\
\text { Potential/ } \\
\text { Centralized } \\
\text { Supply } \\
\text { Replaceability } \\
\left(\mathrm{D}_{\mathrm{r}} / \mathrm{P}\right) \\
(\%)\end{array}$ & $\begin{array}{l}\text { Rainfall } \\
\text { Potential Total } \\
\text { Use } \\
\text { Replaceability } \\
(\mathrm{P} / \mathrm{T}) \\
(\%)\end{array}$ & $\begin{array}{l}\text { Wastewater } \\
\text { Potential/ } \\
\text { Centralized } \\
\text { Supply } \\
\text { replaceability } \\
(\mathrm{Wr} / \mathrm{C}) \\
(\%)\end{array}$ & $\begin{array}{l}\text { Wastewater } \\
\text { Potential/ } \\
\text { Total Use } \\
\text { replaceability } \\
(\mathrm{Wr} / \mathrm{T}) \\
(\%)\end{array}$ & $\begin{array}{l}\text { Stormwater } \\
\text { Potential/ } \\
\text { Centralized } \\
\text { Supply } \\
\text { replaceability } \\
\text { ( R/C) } \\
\text { (\%) }\end{array}$ & $\begin{array}{l}\text { Stormwater } \\
\text { Potential/ } \\
\text { Total Use } \\
\text { replaceability } \\
\left(\mathrm{R}_{\mathrm{S}} / \mathrm{T}\right) \\
(\%)\end{array}$ & $\begin{array}{l}\text { Stormwater and } \\
\text { Wastewater } \\
\text { combined } \\
\text { Potential/ } \\
\text { Total Use } \\
\text { Replaveability } \\
(\mathrm{Rs}+\mathrm{Wr}) / \mathrm{T} \\
(\%)\end{array}$ & $\begin{array}{l}\text { Water Loss } \\
\text { Recovery } \\
\text { Potential/Cent } \\
\text { ralized Supply } \\
\text { replaceability } \\
\text { (Cufw /C) } \\
\text { (\%) }\end{array}$ & $\begin{array}{l}\text { Water Loss } \\
\text { Recovery } \\
\text { Potential/ } \\
\text { Total Use } \\
\text { replaceability } \\
\text { (Cufw /T) } \\
\text { (\%) }\end{array}$ \\
\hline 52 & 0.005 & 12 & 107 & 56 & 12 & 6 & 62 & 53 & 27 \\
\hline
\end{tabular}




\title{
Scenario Analysis
}

\begin{abstract}
Water demand in Bangalore in 2013 was 1260 MLD and in 2014 and 2021, it will be 1320 MLD and 1650 MLD respectively using 120 lpcd and population 10.45, 11 and 13.75 million respectively (adding 10\% more slum people and other unaccounted people such as daily migrated flux).
\end{abstract}

From this study, the actual water supply in 2013 was 927 MLD and the actual gap was 815 MLD. This gap could easily be met in 2013 if even 54\% of 1.5 GL daily potential was harnessed. Current (2014) gap is about 675 MLD and actual supply is 754 MLD (adding 500 MLD Cauvery Stage-IV Phase-II-supply and considering 52.8\% UFW) and in 2021, the water supply gap will be around 895 MLD (if 2013 UFW 52.8\% prevails). The gap in 2014 and 2021 can be met if $45 \%$ and $60 \%$ of this potential (1.5 GL daily) respectively can be recycled or reused. The water demand and actual supply available under prevailing condition and recycling need can be represented in figure-S.

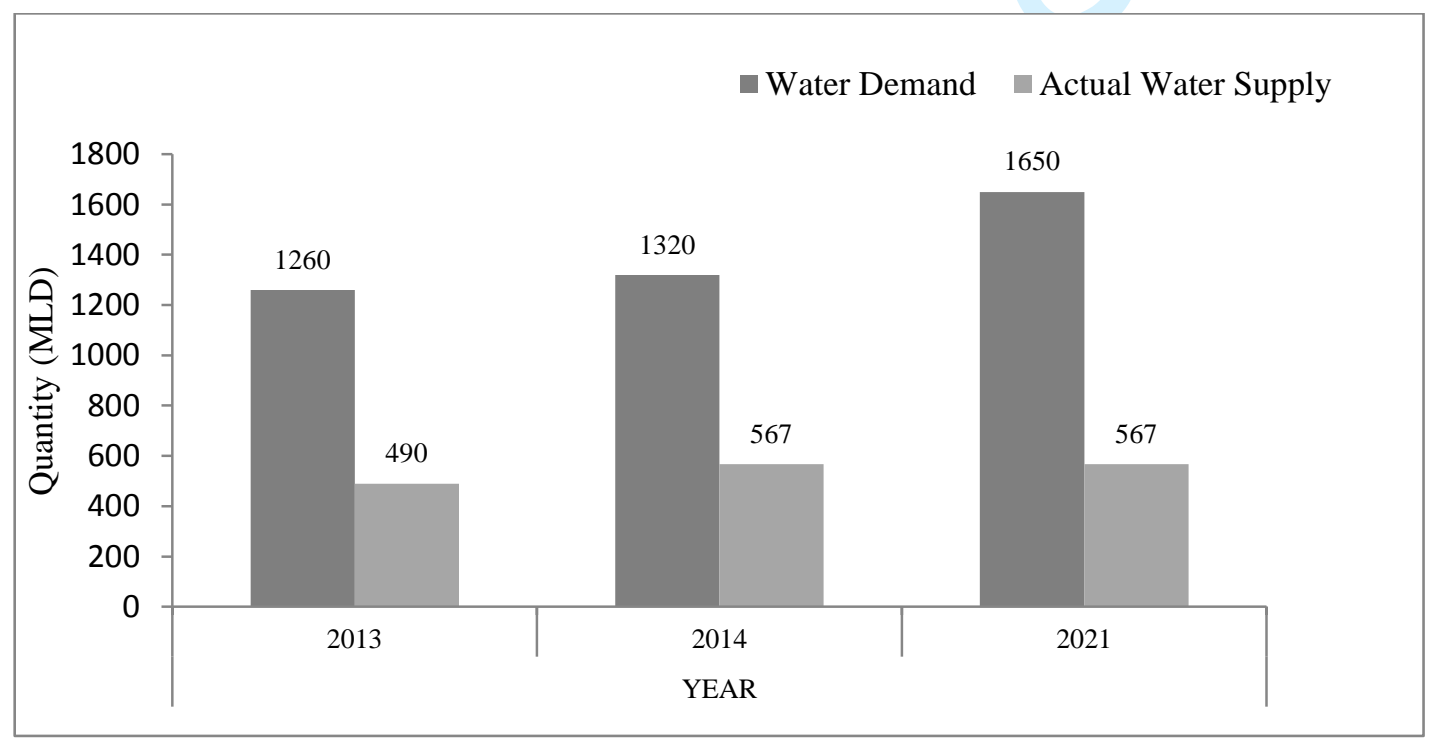

Figure S 6: Water Demand and Supply Scenario in Bangalore city

This is a proof for the purpleses of peer review only. 
1

2

3

4

5

6

7

8

9

10

11

12

13

14

15

16

17

18

19

20

21

22

23

24

25

26

27

28

29

30

31

32

33

34

35

36

37

38

39

40

41

42

43

44

45

46

47

48

49

50

51

52

53

54

55

56

57

58

59

60

\begin{abstract}
Assumption=No recycle and no further withdrawal of water from the Cauvery and considering $52.8 \%$ system loss Water Demand based on 120 lpcd and including $10 \%$ more slum population which is not counted in population Projection of Bangalore city. Though standard per capita in water demand in Bangalore city is $150 \mathrm{lpcd}$, conservative estimation of $120 \mathrm{lpcd}$ was considered. Further water loss was considered $52.8 \%$ as found from the actual investigation in the field. Such conservative estimation can supplement per capita water demand more than 120 lpcd.
\end{abstract}

This is a proof for the purploses of peer review only. 


\section{References}

Bangalore Water Supply and Sewerage Board (BWSSB). 2013. BWSSB Presentation, Bangalore, India.

Bangalore Water Supply and Sewerage Board (BWSSB). 2014. www.bwssb.gov.in.accessed 2014

Bangalore Water Supply and Sewerage Board (BWSSB) a. 2014. Rainwater Guidelines BWSSB, bwssb.org/pdf/Guidlines.pdf. Accessed in April, 2014

Butler, D. and J. W. Davis. 2011, Runoff Coefficient, Forman, R.T.T. Urban Ecology: Science of Cities, p-383, Cambridge, Harvard University, USA.

Census of India. 2001. Provisional population totals, census of India, 2001; urban agglomerations/cities having population 1 lakh and above, New Delhi, India.

Census of India. 2011. Provisional population totals, census of India, 2011; urban agglomerations/cities having population 1 lakh and above, New Delhi, India.

Center for Science and Environment (CSE). 2011. Water waste Portrait. http://cseindia.org/userfiles/bangaluru_portrait.pdf. Accessed in November, 2013.

Central Groundwater Board (CGWB). 2011.Groundwater scenario in major cities of India. Faridabad. Ministry of Water Resources. Government of India.

Central Groundwater Board (CGWB). 2013. Groundwater Information Booklet: Bangalore Urban District. Ministry of Water Resources. Government of India.

Central Groundwater Board (CGWB). 2009. Details Guidelines for Implementing the Groundwater Estimation Methodology. Ministry of water Resources. Government of India

Citizen Matters. 2013. http://bengaluru.citizenmatters.in/587-rwh-guide-587. Accessed in April, 2014

City Development Authority (CDA). 2009. Bangalore Master Plan 2015. Bangalore, India.

Deccan Herald. 2013, Only 44,000 houses in City have RWH, published on 26 Feb, www.deccanherald.com/content/315171/only-44000- houses-city-have.html. Accessed in April, 2014.

Department of Water Resources (DoWR) 2011. The Karnataka Groundwater Act. Department of Water Resources. Government of Karnataka. Bangalore.

FirstPost. 2013. Will Bangalore have to be evacuated by 2023. www.firstpost.com/india/will bangalore-have-to-be-evacuated-by-2023-697649.html. Accessed in April, 2014

Global Voices. 2013. Water Shortage Crisis looms Large in Bangalore, India, http://globalvoicesonline.org/2013/07/26/water-shortage-crisis-looms- large-in Bangaloreindia/. Accessed in November, 2013

Green Governance (GG). 2013. People's Voices Do Matter, Volume-1, Number-4.

This is a proof for the purpzoses of peer review only. 
Grönwall, J. T. 2008. Access to water: Rights, obligations, and the Bangalore situation. Ph.D., Linköping University.

Gronwall, J. T., M. Mulenga, and G. McGranahan. 2010. Groundwater, self-supply and poor urban dwellers: A review with case studies of Bangalore and Lusaka, Water and Sanitation -26, Human Settlements Working Paper Series, IIED, ISBN: 978-1-84369-770-1.

Groundwater Estimation Committee (GEC). 1997. The Groundwater Estimation Methodology, Ministry of Water Resources. Government of India

Hegde, G. V. and K. C. Subhash. 2012. Resource availability for water supply to Bangalore city. Karnataka, Science Correspondence. Current Science Vol. 102, No. 8, 25.

International Business Machines (IBM). 2010. Rain to Drain: A roadmap to gaining control over water resource management using Information management and predictive analytics, NY, USA.

Indian Institute for Human Settlements (IIHS). 2014. Final Urban Diagnostic for Bangalore, Atkins International Ltd in partnership with UCL, The Climate and Development Knowledge Network Project Report, DFID and DGIS, Bangalore, India.

Indiaonlinepags. 2014. Population of Bangalore. www.indiaonlinepages.com/population/bangalorepopulation.html. Accessed in April, 2014

Indian Institute of Science (IISc). 2012. Urban Water Supply and Management. cistup.iisc.ernet.in/presentations/Research\%20project/CIST012.pdf. Accessed in April, 2014

Meteorological Centre Bangalore (MCB). 2014. http://www.imdbangalore.gov.in/. accessed in April, 2014

Ministry of Water Resources (MOWR). 2009. Ground Water Resource Estimation Methodology, report of Ground Water Resource Estimation Committee, Government of India, Bangalore.

Ramachandra, T. and U. Kumar. 2008. Wetlands of Greater Bangalore, India: automatic delineation through pattern classifiers. Electronic Green Journal [Online], 1, 26, Available: http://escholarship.org/uc/item/3dp0q8f2 [Accessed July 29, 2013].

Ravindra, P.N. 2013. Reuse and Recycle. www.elcia.in/images/Sustainability/Ravindra.pdf viewed on 15 February 2014, BWSSSB, Bangalore. Accessed in February, 2014

The Hindu. 2014, Karnataka resorts to load-shedding. www.thehindu.com/todays-paper/tp national/karnataka-resorts-to-loadshedding/article5980608.ece. Accessed in April, 2013

Vishawnath,S. 2012. Domestic Rainwater Harvesting: Some Application in Bangalore, India.

Vishwanath, S. 2001. Domestic Rainwater Harvesting, Bangalore. India. 


\section{About the Authors}

1. Reba Paul was a Masters Student at University of Queensland, Australia when the article was written. Now she is a PhD Student and Research Assistant at Institute for Sustainable Futures (ISF) in the University of Technology Sydney (UTS), Australia.

2. Steven Kenway is an Associate Professor and Research Group Leader for WaterEnergy-Carbon Group at School of Chemical Engineering in University of Queensland (UQ), Brisbane, Australia.

3. Brian McIntosh is an Education Director at International Water Centre (IWC) and Senior Lecturer in the University of Queensland (UQ), Brisbane, Australia.

4. Pierre Mukheibir is an Associate Professor and Research Director at Institute for Sustainable Futures (ISF) in the University of Technology Sydney (UTS), Australia. 
Figure 1: Inputs and Outputs of water flows in selected cities (Source: Kennedy et al. 2007) Note: $\mathrm{t} / \mathrm{cap} / \mathrm{yr}$. = tons/capita/year. One ton $(\mathrm{t})=103$ kilograms (weight of 1 kiloliter water). So $\mathrm{t} / \mathrm{cap} / \mathrm{yr}$. can be represented in volume as $\mathrm{kL} / \mathrm{cap} / \mathrm{yr}$.

$130 \times 49 m m(96 \times 96$ DPI)

This is a proof for the purposes of peer review only. 


\section{System Boundary (B)}

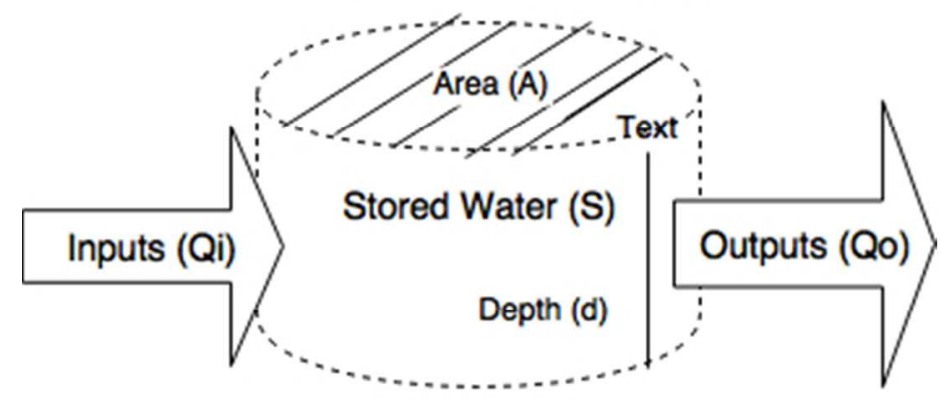

(a)

Figure 2: a) Defining System Boundary (Sources: adapted from Kenway et al. 2011).

92×55mm (96 x 96 DPI)

This is a proof for the purposes of peer review only. 
Figure 2: b) Water Mass Balance Framework considering groundwater under the urban entity and storages outside the urban entity (Sources: adapted from Kenway et al. 2011).

99x90mm (96 x 96 DPI)

This is a proof for the purposes of peer review only. 


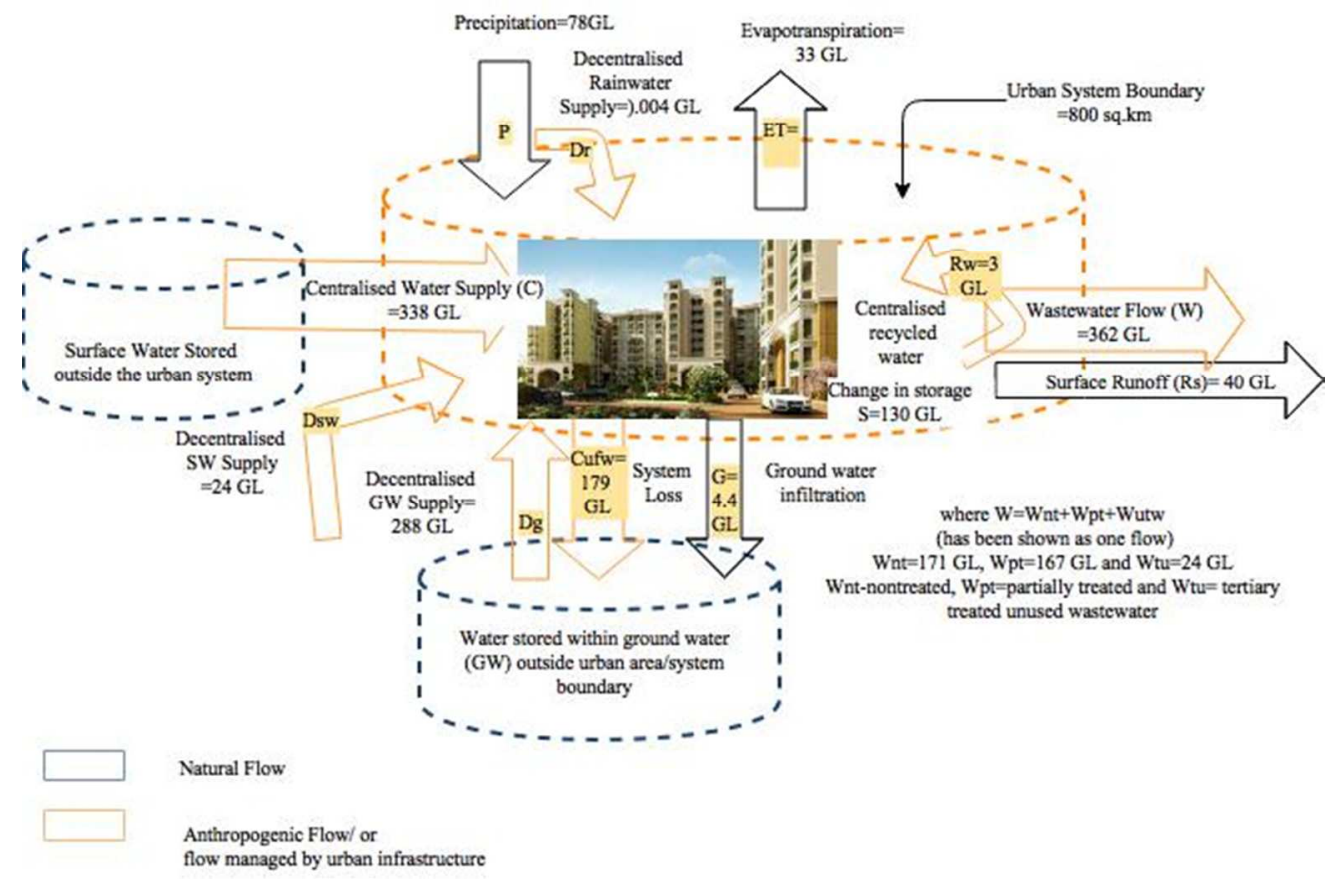

Figure 3: Water Mass Balance Evaluation Framework (Refinement of original framework developed by Kenway et al. (2011) to apply for a developing country context)

\section{$229 \times 154 \mathrm{~mm}(72 \times 72 \mathrm{DPI})$}

This is a proof for the purposes of peer review only. 


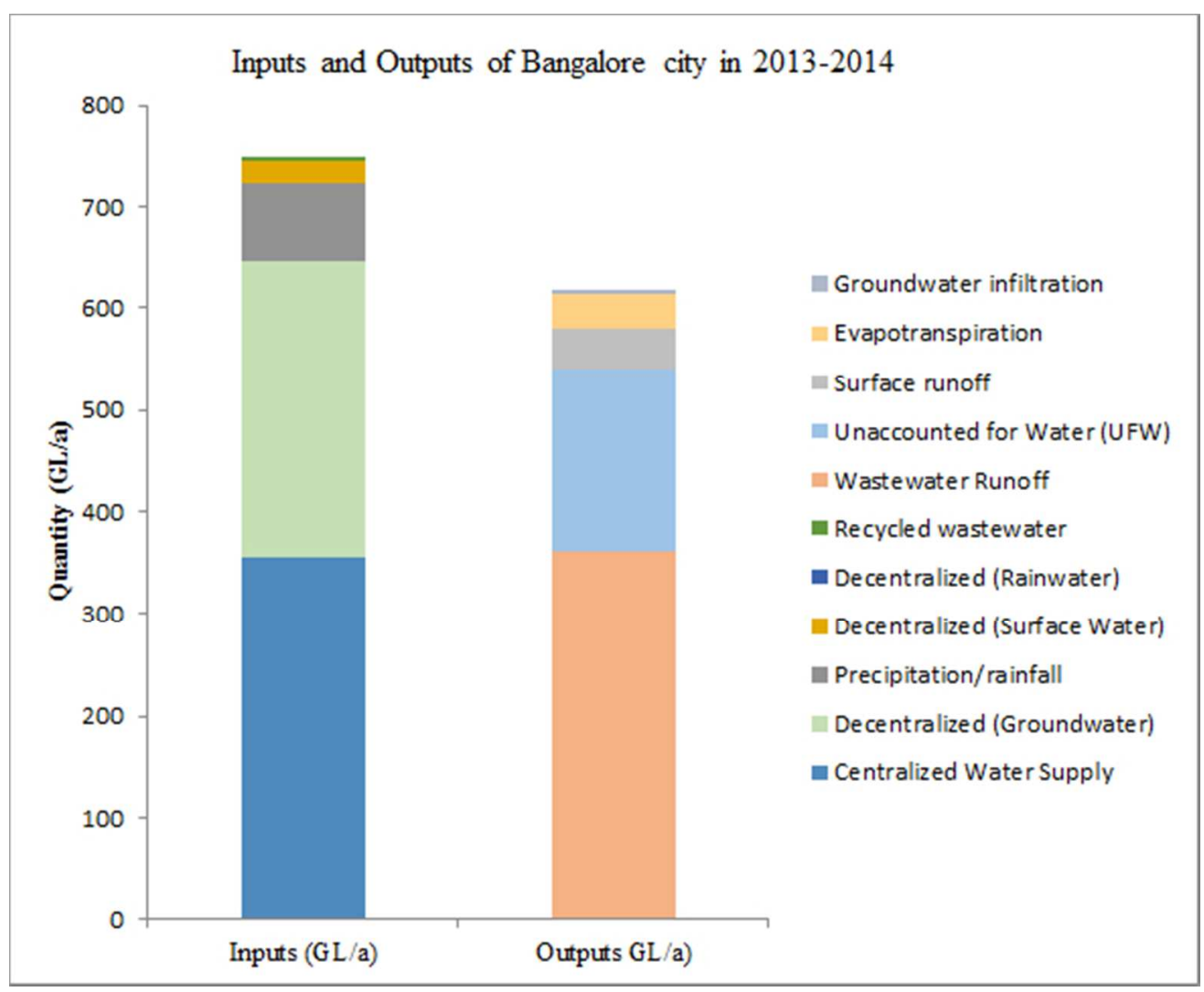

Figure 4: Inputs and Outputs of water in Bangalore city for the year 2013-1014.

$$
155 \times 127 \mathrm{~mm}(96 \times 96 \mathrm{DPI})
$$

This is a proof for the purposes of peer review only. 
Table 1: Performance indicators and their definition under the study

\begin{tabular}{|c|c|c|}
\hline Indicators & Method & Formula \\
\hline $\begin{array}{l}\text { Water System } \\
\text { Centralization Supply } \\
\text { centralization }(\%)\end{array}$ & $\begin{array}{l}\text { Centralized Supply/Total Water } \\
\text { Use }\end{array}$ & $\mathrm{C} /(\mathrm{C}+\mathrm{D}) * 100$ \\
\hline $\begin{array}{l}\text { Rainfall Harvesting }(\%) \\
\text { Rainfall Potential for Water Supply } \\
\text { Centralized supply replaceability } \\
(\%) \text { Total Use Replaceability }(\%)\end{array}$ & $\begin{array}{l}\text { Decentralized sources/rainfall } \\
\text { Rainfall/Centralized water } \\
\text { supplied Rainfall/Total Use }\end{array}$ & $\begin{array}{l}\mathrm{D} / \mathrm{P} * 100 \\
\mathrm{P} / \mathrm{C}^{*} 100 \\
\mathrm{P} /(\mathrm{C}+\mathrm{D}) * 100\end{array}$ \\
\hline $\begin{array}{l}\text { Wastewater Potential for Water } \\
\text { Supply Centralized Supply } \\
\text { Replaceability (\%) Total Use } \\
\text { Replaceability (\%) }\end{array}$ & $\begin{array}{l}\text { Wastewater Flow/Centralized } \\
\text { water supplied } \\
\text { Wastewater Flow/Total Water Use }\end{array}$ & $\begin{array}{l}\mathrm{W} / \mathrm{C} * 100 \\
\mathrm{~W} /(\mathrm{C}+\mathrm{D}) * 100\end{array}$ \\
\hline $\begin{array}{l}\text { Stormwater Potential for Water } \\
\text { Supply Centralized Supply } \\
\text { Replaceability (\%) Total Use } \\
\text { Replaceability (\%) }\end{array}$ & $\begin{array}{l}\text { Stormwater flow/centralized } \\
\text { water supplied } \\
\text { Stormwater flow/Total } \\
\text { Water Supplied }\end{array}$ & $\begin{array}{l}\mathrm{Rs} / \mathrm{C}^{*} 100 \\
\mathrm{Rs} /(\mathrm{C}+\mathrm{D})^{*} 100\end{array}$ \\
\hline $\begin{array}{l}\text { Wastewater and stormwater } \\
\text { combined Potential of 'total water } \\
\text { use Replaceability' (\%) }\end{array}$ & $\begin{array}{l}\text { (Wastewater+stormwater)/ } \\
\text { Total water use }\end{array}$ & $(\mathrm{W}+\mathrm{Rs}) /(\mathrm{C}+\mathrm{D})^{*} 100$ \\
\hline $\begin{array}{l}\text { Water Loss Recovery Potential of } \\
\text { 'total water use Replaceability' (\%) }\end{array}$ & Water Loss/Total water use & $\mathrm{Cufw} /(\mathrm{C}+\mathrm{D})^{*} 100$ \\
\hline
\end{tabular}

Source: Adapted from Kenway et al. (2011)

Note- $\mathrm{C}=$ Total Centralized Water Supply, D=Total Decentralized Water Supply, P= Rainfall, $\mathrm{W}=$ Wastewater Flow, Rs $=$ Stormwater Runoff, $\mathrm{Cufw}=$ Uncounted For Water

This is a proof for the purposes of peer review only. 
Table 2: Inputs (Qi) and Outputs (Qo) of Bangalore city for the year 2013-2014

\begin{tabular}{|c|c|c|c|c|c|c|c|c|}
\hline Inputs & $\begin{array}{l}\text { Population } \\
\text { (Million) }\end{array}$ & $\begin{array}{l}\text { Area } \\
(\mathrm{Sq} . \\
\mathrm{km})\end{array}$ & $\begin{array}{l}\text { Centralized } \\
\text { Surface } \\
\text { Water } \\
\text { Supply } \\
\text { (GL/a) } \\
\end{array}$ & $\begin{array}{l}\text { Decentralized } \\
\text { Groundwater } \\
\text { Supply } \\
\text { (GL/a) }\end{array}$ & $\begin{array}{l}\text { Decentralized } \\
\text { Surface Water } \\
\text { Supply (GL/a) }\end{array}$ & $\begin{array}{l}\text { Decentralized } \\
\text { rainwater } \\
\text { supply(rainw } \\
\text { ater tank) } \\
(\mathrm{GL} / \mathrm{a})\end{array}$ & $\begin{array}{l}\text { Rainfall } \\
\text { on } \\
\text { Surface } \\
\text { (GL/a) }\end{array}$ & $\begin{array}{l}\text { Reuse of } \\
\text { Wastewater } \\
\text { (G/a) }\end{array}$ \\
\hline & 9.5 & 800 & 356 & 288 & 24 & 0.004 & 78 & 3 \\
\hline Outputs & $\begin{array}{l}\text { Population } \\
\text { (Million) }\end{array}$ & Area & $\begin{array}{l}\text { Partially } \\
\text { Treated } \\
\text { Waste } \\
\text { water } \\
\text { Flow } \\
(\text { GL/a) }\end{array}$ & $\begin{array}{l}\text { Non-Treated } \\
\text { Wastewater } \\
\text { Flow } \\
(\mathrm{GL} / \mathrm{a})\end{array}$ & $\begin{array}{l}\text { Treated } \\
\text { Wastewater } \\
\text { Flow } \\
(\text { GL/a) }\end{array}$ & $\begin{array}{l}\text { Surface } \\
\text { Runoff } \\
(\mathrm{GL} / \mathrm{a})\end{array}$ & $\begin{array}{l}\text { System } \\
\text { Loss } \\
(\mathrm{GL} / \mathrm{a})\end{array}$ & $\begin{array}{ll}\text { Ground } & \text { Evapo- } \\
\text { Water } & \text { Transp } \\
\text { Recharge } & \text { iration } \\
(\text { GL/a) } & (\text { GL/a) }\end{array}$ \\
\hline & 9.5 & 800 & 167 & 171 & 24 & 40 & 179 & 4.4 \\
\hline
\end{tabular}

Note: GL/a = Gigaliter /annum 
Table 3: Centralized Supply Replaceability/ Supply Substitution of alternative sources of water including loss in the system for the year 2013-2014

\begin{tabular}{|c|c|c|c|c|c|c|c|}
\hline & & & \multicolumn{5}{|c|}{$\%$ of potential replaceability/substitution of water supply } \\
\hline Supply & $\begin{array}{l}\% \\
\text { Total } \\
\mathrm{C} /(\mathrm{C}+\mathrm{D}) \\
* 100\end{array}$ & $\begin{array}{l}\text { of Rain } \\
\text { Water } \\
(\mathrm{P} / \\
\left.\mathrm{C}^{*} 100\right)\end{array}$ & $\begin{array}{l}\text { Storm } \\
\text { Water } \\
\text { (RS/ } \\
\left.C^{*} 100\right)\end{array}$ & $\begin{array}{l}\text { Waste } \\
\text { Water } \\
(\mathrm{W} / \\
\left.\mathrm{C}^{*} 100\right)\end{array}$ & $\begin{array}{l}\text { Unaccounted } \\
\text { For Water } \\
\text { (UFW)/Non- } \\
\text { Revenue } \\
\text { Water } \\
\text { (NRW)(Cufw } \\
\text { / C*100) }\end{array}$ & $\begin{array}{l}\text { Waste } \\
\text { water and } \\
\text { Rainwater } \\
\left(\mathrm{W}+\mathrm{P} / \mathrm{C}^{*}\right. \\
100)\end{array}$ & $\begin{array}{l}\text { All alternative } \\
\text { waters } \\
(\mathrm{W}+\mathrm{P}+\mathrm{Rs}) / \\
\mathrm{C} * 100\end{array}$ \\
\hline Centralized & 52 & 23 & 12 & 107 & 53 & 130 & 195 \\
\hline
\end{tabular}

This is a proof for the purposes of peer review only. 
Table 4: 'Total Use Replaceability'/ Supply Substitution of alternative sources of water including loss in the system for the year 2013-2014 